\title{
Who is Moina micrura? Redescription of one of the most confusing cladocerans from terra typica, based on integrative taxonomy
}

\author{
Manuel Elías-Gutiérrez ${ }^{1,}$, Petr Jan Juračka ${ }^{2}$, Lucía Montoliu-Elena ${ }^{1,3}$, Maria Rosa Miracle†, \\ Adam Petrusek ${ }^{2}$ and Vladimír Kořínek ${ }^{2}$ \\ ${ }^{1}$ El Colegio de la Frontera Sur, Unidad Chetumal, Av. Centenario Km 5.5, Chetumal 77014, Quintana Roo, \\ México. \\ ${ }^{2}$ Charles University, Faculty of Science, Department of Ecology, Viničná 7, Prague 2, Czech Republic. \\ 3 Posgrado en Ciencias del Mar y Limnología, Universidad Nacional Autónoma de México; Av. Ciudad Univer- \\ sitaria 3000, ZIP. 04510, Coyoacán, Ciudad de México, México. \\ $\dagger$ University of Valencia (deceased). \\ * Corresponding author: melias@ecosur.mx
}

Received: $15 / 02 / 18 \quad$ Accepted: 24/09/18

\begin{abstract}
Who is Moina micrura? Redescription of one of the most confusing cladocerans from terra typica, based on integrative taxonomy

Moina micrura Kurz, 1875 (Anomopoda: Moinidae) belongs among the most poorly defined cladoceran species in the world. This species has been considered cosmopolitan and is widely used for laboratory experiments, ecotoxicology, physiology or as live food. Nevertheless, recent molecular analyses corroborated the idea that it is a diverse complex of closely related species. Persisting systematic problems with M. micrura stem from the fact that it has not been redescribed in detail, and its type material as well as the type locality are lost. With this study, we try to provide a redescription, using morphology of females, males and ephippial females and the DNA barcodes for M. micrura s. str. from the pond situated not far from its original type locality in the Czech Republic. Firstly, we sequenced mitochondrial genes for cytochrome c oxidase subunit I (COI) and the 12S rDNA to establish the identity of M. micrura s. str. After this analysis, we compared the genetic data with all available sequences across the world. The species seems restricted to the Western Palearctic, with the most easterly located genetically confirmed records from Kazakhstan and Israel. The closest related lineage to M. micrura s. str. was found in Spain and needs a thorough analysis to establish its systematic status. M. micrura s. str. has unique features in the posterior spinulation of the valves of the parthenogenetic female, and the ornamentation of the ephippium. In the male, spinules on the tip of the antennule and the hook on the first thoracopod are also unique. With this description, we hope to inspire specialists to start uncovering the diversity of this complex, to understand its biogeography and diversity, as well as the real range of M. micrura s. str.
\end{abstract}

Key words: Cladocera, systematics, taxonomy, species complex, Western Palaearctic

\section{RESUMEN}

¿Quién es Moina micrura? Redescripción de uno de los cladóceros más confusos a partir de su terra typica, basada en la taxonomía integrativa

Moina micrura Kurz, 1875 (Anomopoda: Moinidae) es una de las especies de cladóceros más confusas del mundo. Durante mucho tiempo fue considerada cosmopolita pero análisis moleculares recientes corroboraron la idea de que es un complejo de especies cripticas estrechamente relacionadas. Los persistentes problemas sistemáticos con M. micrura derivan de la falta de una redescripción detallada y de que tanto su material tipo como la localidad tipo han desaparecido. La importancia de esta especie radica en que es utilizada en diversos experimentos de índole ecotoxicológica, fisiológica, como alimento vivo, etc. Con este estudio, tratamos de proporcionar una redescripción de M. micrura s. str, utilizando la morfología de las hembras partenogenéticas, efipiales y de los machos, asi como caracteres adicionales como los códigos de barras de ADN. El material 
estudiado procede de un estanque situado cerca de la localidad tipo original en la República Checa. En primer lugar, se secuenciaron los genes mitocondriales citocromo c oxidasa subunidad I (COI o códigos de barras) y el 12S a fin de establecer la identidad de M. micrura s. str. Después de este análisis, se compararon las secuencias obtenidas con todas las secuencias publicadas disponibles de esta especie a nivel mundial. Aparentemente, M. micrura s. str. está restringida al Paleártico, con registros confirmados molecularmente en República Checa, Eslovaquia, Kazajstán e Israel. El linaje más próximo a M. micrura s. str. se encontró en España pero se necesita un análisis más exhaustivo para establecer con certeza su identidad. M. micrura s. str. presenta características únicas como la espinulación posterior de las valvas de la hembra, y la ornamentación del efipio. En el macho, las espínulas en la punta de la antena y el gancho del primer toracópodo también son únicos. Con esta descripción, esperamos que los especialistas tengan una referencia clara para descubrir la diversidad de este complejo, así como comprender su biogeografía y diversidad.

Palabras clave: Cladocera, sistemática, taxonomía, complejo de especies, Paleártico occidental

\section{INTRODUCTION}

Moina micrura, seemingly one of the most ubiquitous cladocerans with apparently worldwide distribution, has been also one of the most taxonomically confused species. It was described by Kurz (1875) from Bohemia (the present-day Czech Republic), in short paragraphs, where no presently relevant taxonomic characters were used. Although the description and accompanying drawings (Fig. 1) were exceptionally good for those times, they lacked fundamental diagnostic characters, and no characters of males or ephippial females were mentioned. Furthermore, the type material is lost and the original locus typicus, a fish pond Mlýnský (Muehlteich) at Malešov village, has been dried out decades ago and the surrounding area forested (Petrusek, 2002). The first attempt to review contemporary knowledge on M. micrura in Bohemia, its terra typica, was published by Šrámek-Hušek (1940), as the validity of Kurz' species was doubted (e.g., Wagler, 1937). Šrámek-Hušek (1940) presented a substantial amount of evidence to support the distinct status of the species, based on the ample material collected in the vicinity of the original type locality.

Later, due to the apparent intraspecific variability within M. micrura, at least three subspecies were described and accepted by specialists. Goulden (1968) in his classic monograph on the systematics of the Moinidae family included seven formerly separate species as younger synonyms of $M$. micrura, and later, two more were synonymized by Smirnov (1976). Since then, a great confusion has been apparent, and regional faunal books display M. micrura descriptions and drawings that do not match each other. For example, Alonso (1996) used Spanish material to illustrate M. micrura, but it differs in details with

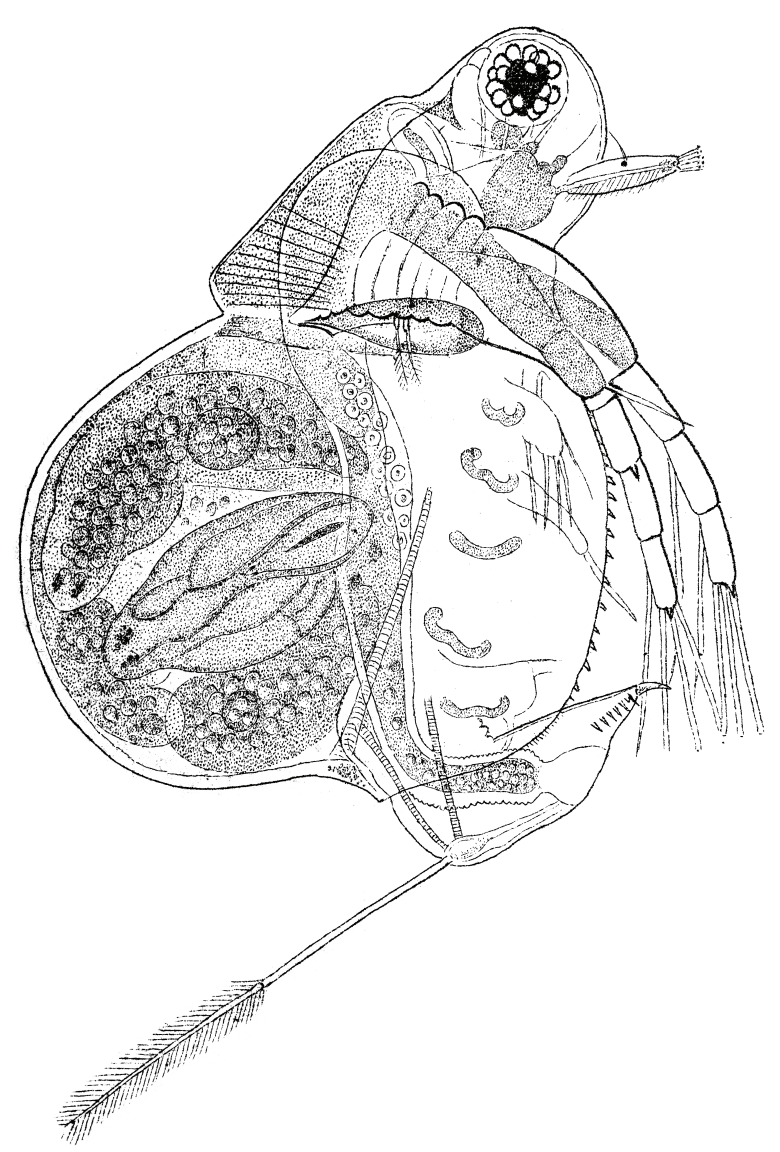

Figure 1. Moina micrura drawn by Kurz (1875) in the original species description. Dibujo de Moina micrura realizado por Kurz (1875) en la descripción original de la especie. 
material from other regions (pers. obs.).

Hudec's publications $(1990 ; 2010)$ contain a very good morphological characterization and figures of M. micrura s. str. based on Central European material from the Danube basin, and also provides diagnostic characters to distinguish it from a superficially similar species also found in the region, Moina weismanni Ishikawa, 1896. However, Hudec's descriptions of $M$. micrura do not include all thoracopods and other important details of the shell, and no molecular data are provided.

M. micrura, presumably widely distributed in Europe, has been also recorded from all other continents except Antarctica. In Asia, it has been reported for example in Turkey (Bekleyen et al., 2008), southern China (Li et al., 2012), Malaysia (Idris, 1983) and India (Chatterjee et al., 2013). The last-mentioned authors regarded Moina dubia Guerne \& Richard, 1892 as a valid species distinct from M. micrura. In the American continent, Elías-Gutiérrez et al. (2008) compiled the records related to this taxon in Mexico and regarded $M$. micrura as a complex of species even within that single country. Particularly in Brazil, presumed M. micrura has been recorded in diverse environments, from freshwaters to a brackish hyper-eutrophic estuary (Paranhos et al., 2013; Paranaguá et al., 2005). It has also been reported from Australia (Smirnov et al., 1983; but see Petrusek et al., 2004) and from the whole African continent (Dumont et al., 1981).

As detailed morphology of most branchiopods remains not satisfactorily described, it is considered that molecular data could help to understand diversity and phylogeny of this group (DeWaard et al., 2006). In the case of M. micru$r a$, as far as we know, at least three studies involved some molecular analyses, but they are partial and do not clarify the taxonomy of this species sufficiently. Petrusek et al. (2004) questioned the apparent cosmopolitanism of $M$. micrura, demonstrating by crossing experiments and molecular characters (sequence divergence of the mitochondrial gene for 12S rRNA) a distinctness of $M$. micrura from the Czech Republic (sampled about $90 \mathrm{~km}$ from the original type locality) from Australian M. micrura-like specimens. However, the genetic comparisons were based only on one clone of both species, and their morphology was not described. Elías-Gutiérrez et al. (2008) found in Mexican populations morphologically similar to $M$. micrura three related but distinct lineages based on the DNA barcodes, i.e., fragments of the cytochrome c oxidase subunit I gene, COI (Hebert et al., 2003a, b). However, they could not compare these lineages with the European populations, because there were no sequences of M. micrura from terra typica available for this gene, which has become the standard marker for identification of animal species, including crustaceans (Eischeid et al., 2016). A recent DNA barcoding-based study uncovered 21 phylogenetic groups of Moina within the Palearctic, with at least three clades of micrura-like taxa from this region (Bekker et al., 2016).

Despite the taxonomical problems, many papers dealing with culture, ecotoxicology, ecology and other topics related to M. micrura have been published recently ( 58 papers are recorded in the main collection of the Web of Knowledge, Thomson Reuters, between 2010 and 2017), obviously due to a wide range and ubiquity of this taxon. However, many - possibly most - of these studies probably do not deal with M. micru$r a$ in a strict sense, and consequently results of such studies are not fully comparable.

The aim of our study is therefore to establish the identity of Moina micrura from its type locality, and to provide a good reference for future comparison and identification of this species. To achieve this goal, we used an integrative taxonomy approach (Dayrat, 2005), combining detailed morphological analyses and additional DNA sequencing for two genes. We also provide a short description of differential characters of Moina weismanni Ishikawa, 1896, as it often co-occurs in ponds with M. micrura within its terra typica (Petrusek, 2002), and their parthenogenetic females are superficially similar. Furthermore, we explored variation in ultrastructure of ephippia, as a potentially highly relevant taxonomic trait (Goulden, 1968; Juracka et al., 2016) in populations of the Moina micrura complex across the globe, and compared them with several other species of the genus. 


\section{MATERIAL AND METHODS}

\section{Field Sampling}

Material of Moina micrura was collected with a plankton $(45 \mu \mathrm{m})$ and a hand net $(90 \mu \mathrm{m})$ from a small fish pond named Sádka (49.963 N, 15.329 E; area 0.85 ha) situated between Ovčáry and Nové Dvory villages, $4.6 \mathrm{~km}$ east from Kutná Hora, in the Czech Republic, very close to the original (now dried up) type locality (Supplementary information, Table S1, available at http://www. limnetica.net/en/limnetica).

\section{Material examined}

All material (see Supplementary information, Tables S1 and S2, available at http://www.limnetica net/en/limnetica) was preserved with non-denatured ethanol and since 2012, the procedure suggested by Prosser et al. (2013) was followed. Samples for intercontinental comparison are from V. Kořínek's collection of Cladocera (www. cladocera-collection.cz) and were originally preserved in $4 \%$ formaldehyde solution and stored in $70 \%$ ethanol.

As Moina micrura s. 1. is widely distributed, we examined ephippial ultrastructure by scanning electron micrography on the material sampled from various continents, including Europe, Asia, Africa, South America, and Australia (see Supplementary information, Table S2) to evaluate morphological variation among populations isolated by large inter-continental distances. However, this variability within the species complex has to be compared also with the material from other well-defined species of the genus to evaluate the extent of interspecific variation. Therefore, we also included in the comparison M. belli, M. brachiata, M. macrocopa, M. mongolica, M. reticulata, M. tenuicornis, as well as morphologically clearly distinct but apparently undescribed lineage from Australia (Supplementary information, Table S2).

\section{Analyses of the material}

\section{Morphological observations}

Specimens were sorted from the ethanol-pre- served samples under a stereomicroscope and placed in a drop of a glycerol. Several females were dissected. Whole animals and dissected sections were examined and measured under a differential interference contrast microscope and/or phase contrast microscope. They were morphologically identified following descriptions by several authors (Goulden, 1968; Alonso, 1996; Hudec, 2010).

Selected individuals were prepared for scanning electron microscopy (SEM). To remove unwanted biofilm covering surface of studied individuals, examined material was cleaned for 10 minutes with hot $10 \%$ potassium hydroxide prior to its dehydration. Dehydration series followed standard graded series of acetone solutions in alcohol 30, 50, 70, 80, 90, 95 and $97 \%$, followed by two immersions in $100 \%$ acetone. Afterwards, we replaced acetone with the hexamethyldisilazane for 20 minutes and left the material overnight in the desiccator. The dried samples were gold-coated and then observed with JEOL JSM-6380 LV scanning electron microscope at $15 \mathrm{kV}$. Further details of the methods are described in Juračka et al. (2016). Ephippial ultrastructure was always studied above the center of the egg chamber.

\section{Selected molecular markers}

Two mitochondrial genes previously sequenced in M. micrura-like animals (12S and COI) were selected as molecular markers also for this study. A fragment of the gene for 12S rRNA (343 bp) was selected to allow comparison with the previously published sequence of $M$. micrura $\mathrm{s}$. str. by Petrusek et al. (2004), and the gene for COI (620 bp) due to its status as a standard barcoding gene in animal kingdom (Hebert et al., 2003a; Eischeid et al., 2016), its frequent use to discriminate cladoceran species (Elías-Gutiérrez et al., 2008), and its availability for various Moina lineages (Elías-Gutiérrez et al., 2008; Bekker et al., 2016).

\section{DNA isolation, PCR amplification and sequencing}

DNA was extracted from whole-body homogenates using a mix of Proteinase $\mathrm{K}$ with invertebrate lysis buffer and digested overnight at $56{ }^{\circ} \mathrm{C}$ for 
material processed before 2011 (see Elías-Gutiérrez et al., 2008). Genomic DNA was subsequently extracted using a membrane-based approach. After 2011, we used the HotShot extraction protocol (Montero-Pau et al., 2008). Approximately $600-658 \mathrm{bp}$ were amplified for the COI using LCO1490 and HCO2198 primers (Folmer et al., 1994) and/or ZPLK primers suggested by Prosser et al. (2013).

The polymerase chain reaction (PCR) reagents used were as follows: $12.5 \mu \mathrm{L}$ of PCR reaction mix included $6.25 \mu \mathrm{l}$ of $10 \%$ trehalose, $2 \mu \mathrm{l}$ of distilled deionized water and $1.25 \mu \mathrm{l}$ of $10 \times \mathrm{PCR}$ buffer for the enzyme Taq Platinum, $0.625 \mu 1$ of $\mathrm{MgCl}_{2}(50 \mathrm{mM}), 0.125 \mu 1$ of each primer, forward and reverse $(0.01 \mathrm{mM}), 0.0625 \mu \mathrm{l}$ of dNTP mix $(10 \mathrm{mM}), 0.06 \mu$ Platinum Taq polymerase (5 $\mathrm{U} / \mu \mathrm{l})$, and $2.0 \mu \mathrm{L}$ of template DNA.

The thermocycler program included initial denaturation at $94{ }^{\circ} \mathrm{C}$ for 1 minute, 5 cycles of 94 ${ }^{\circ} \mathrm{C}$ for 40 seconds, $45{ }^{\circ} \mathrm{C}$ for 40 seconds, $72{ }^{\circ} \mathrm{C}$ for 1 minute, 35 cycles of $94^{\circ} \mathrm{C}$ for 40 seconds, $51^{\circ} \mathrm{C}$ for 40 seconds, $72{ }^{\circ} \mathrm{C}$ for 1 minute, and a final extension at $72{ }^{\circ} \mathrm{C}$ for 5 minutes.

For $12 \mathrm{~S}$, the PCR reaction mix was identical to that of COI but primers L13337-12S and H13842-12S were used (Machida et al., 2004). The PCR was performed under following conditions: $95^{\circ} \mathrm{C}$ at $4 \mathrm{~min}$, followed by 40 cycles of 94 ${ }^{\circ} \mathrm{C}$ for 45 seconds, $60{ }^{\circ} \mathrm{C}$ for 45 seconds, $72{ }^{\circ} \mathrm{C}$ for 90 seconds, and the final extension step at $72{ }^{\circ} \mathrm{C}$ for 6 minutes. PCR products were visualized on pre-cast agarose gels (E-Gels ${ }^{\odot}$, Invitrogen). They were then sequenced bidirectionally using an $\mathrm{ABI}$ 3730 (Applied Biosystems) capillary sequencer using the BigDye ${ }^{\mathcal{O}}$ Terminator v3.1 Cycle Sequencing Kit (Applied Biosystems), as described in Hajibabaei et al. (2005).

\section{Sequence analysis}

COI sequences obtained in this study (Supplementary information, Table S1) were combined with those for M. micrura and other members of this genus available in GenBank and Barcode of Life Database (BOLD, boldsystems.org) (Supplementary information, Table S1), to examine clade diversity. All sequences generated from this study are in the dataset DS-MICRSSTR Moina micrura s. str. description in BOLD and GenBank (see Supplementary information, Table S1 for accession numbers).

Alignments and calculations were made with the tools provided by BOLD (Ratnasingham et $a l ., 2007)$. COI sequences were aligned with BOLD aligner (Amino Acid based HMM) and $12 \mathrm{~S}$ sequences were aligned with Kalign algorithm (Lassmann et al., 2005). Nucleotide divergence was calculated using the Kimura two-parameter (K2P) algorithm (Kimura, 1980) with complete deletion of gaps and missing data. Neighbour-joining (NJ) trees (Saitou et al., 1987) based on K2P distances (ID Tree) were created to provide a graphic representation of divergence patterns among species and lineages. For COI-based analyses, a sequence of Moina macrocopa from Texcoco Lake (Mexico) was used as outgroup; a sequence of Moina macrocopa from Kostelec (Czech Republic) was used for the same purpose when analysing 12S sequences (see Supplementary information, Table S1).

We also performed a maximum likelihood analysis with the MEGA6 software (Tamura et al., 2013). A maximum likelihood tree was constructed using the General Time Reversible model with Gamma distributed and invariant sites (GTR G+I) as the best fitting model of substitution. Gamma distribution was approximated using five rate categories and nearest-neighbour interchange was used as heuristic method for tree inference. Nodal support for the resulting branches was estimated with 1000 bootstrap replications. The subtrees for terminal clades were collapsed for visualization in MEGA6.

\section{Delimitation of groups within the M. micrura complex}

Molecular operational taxonomic units (OTU's) have frequently been used to infer putative species boundaries where morphological identifications are difficult (Ashfaq et al., 2015). We used two approaches to assign the $12 \mathrm{~S}$ and COI sequences presumably belonging to the $M$. micru$\mathrm{ra}$ species complex to OTU's: Barcode Index Number (BIN) system (Ratnasingham et al., 2013) and Automatic Barcode Gap Discovery (ABGD; Puillandre et al., 2012). The BIN system 
Table 1. Genetic divergences (K2P) among the $12 \mathrm{~S}$ (A) and COI (B) sequences for M. micrura s. 1. All divergences are calculated as comparisons to M. micrura s. str. from the fishpond Sádka at Nové Dvory, the locality from which a neotype was selected. *Needs a revision to evaluate its distinctness or conspecifity with $M$. micrura s. str. **Only one sequence is available. Divergencias genéticas (K2P) entre las secuencias de los genes $12 s$ (A) y COI (B) para M. micrura s.l. Todas las divergencias están calculadas como comparaciones con M. micrura s. str. del estanque de peces Sádka en Nové Dvory, la localidad de donde fue selecciona el neotipo. *Necesita una revisión para evaluar su diferencia o co-especificidad con M. micrura s.str. **Solo una secuencia se encuentra disponible.

(A)

\begin{tabular}{ccc}
\hline Country & Locality (clade) & 12S divergence \\
\hline \multirow{2}{*}{ Czech Republic } & Sádka & 0 \\
& Dobř́ńn & 0.19 \\
& Ovč́ry & 0 \\
\hline \multirow{4}{*}{ Spain } & Albufera lake (1 ES) & $1.32^{*}$ \\
& Sobron reservoir (1 ES) & $1.32^{*}$ \\
& Albufera lake (2 ES) & 8.96 \\
& Zahillo (3 ES) & 11.31 \\
\hline Israel & Kinneret & 0 \\
\hline Ethiopia & Dibdibo & 6.46 \\
\hline Slovakia & Hrhov & 0.19 \\
\hline Hungary & Czista Puszta & 10.22 \\
\hline Australia & Albury & 8.95 \\
\hline
\end{tabular}

(B)

\begin{tabular}{ccc}
\hline & \multicolumn{2}{c}{ COI Divergence } \\
\cline { 2 - 3 } Country (lineage) & $\begin{array}{c}\text { Min Dist } \\
\mathbf{( \% )}\end{array}$ & $\begin{array}{c}\text { Max Dist } \\
\mathbf{( \% )}\end{array}$ \\
\hline Czech Republic & $0^{* *}$ & $0^{* *}$ \\
Kazakhstan & 0.46 & 0.46 \\
Spain (1 ES) & 4.64 & 4.64 \\
India & 11.58 & 11.58 \\
Spain (2 ES) & 15.34 & 15.34 \\
Russia & 17.68 & 18.09 \\
South Korea, Russia, Hungary & 15.99 & 15.99 \\
Mexico (MX 1) & 15.24 & 16.37 \\
Mexico (MX 2) & 15.11 & 15.46 \\
Mexico (MX 3) & 13.28 & 14.30 \\
Mexico (MX 4) & 14.70 & 14.70 \\
Mexico (MX 5) & 13.52 & 13.52 \\
\hline
\end{tabular}


is based in the Refined Single Linkage (RESL) algorithm to reach decisions on the number of OTU's in a sequence dataset through a three-phased analysis. ABGD employs a multi-phase system which initially divides sequences into OTUs based on a statistically inferred barcode gap (i.e., initial partitioning), and subsequently conducts additional rounds of splitting (i.e., recursive partitioning). The COI and $12 \mathrm{~S}$ sequences were analyzed with an online version of ABGD (http://wwwabi.snv.jussieu.fr/ public/abgd/abgdweb.html) using K2P as the distance metric, employing a relative gap (X) of 1.5, a minimal intraspecific distance (Pmin) of 0.001 , and a maximal intraspecific distance (Pmax) ranging from 0.02 to 0.1 .

\section{RESULTS}

\section{Sequence analysis}

Kimura 2-parameter (K2P) distances among the $12 \mathrm{~S}$ and COI sequences of putative M. micrura from various regions ranged from 0 to $11.3 \%$ and from 0.27 to $18.09 \%$, respectively (Table 1 , A and B). COI gene is less conservative than $12 \mathrm{~S}$, hence divergences are bigger. COI sequences with divergences exceeding $3 \%$ were considered to belong to different groups (Hebert et al., 2003b).

Analyzing the results of both genes and using the above-mentioned divergence threshold of 3 $\%$, Moina micrura s. str. has been confirmed in the Czech Republic, Israel (Lake Kinneret; in this case using the $12 \mathrm{~S}$ fragment, with $0 \%$ divergence) and European part of Kazakhstan (near Ushkempir). The other groups represent nine divergent lineages, potentially cryptic species, of the M. micrura complex, the most closely related one originating from Spain.

\section{Comparison of $12 \mathrm{~S}$ and $\mathrm{COI}$ sequence variation}

The results of the ID tree analysis in BOLD (Fig. S1, Available at http://www.limnetica.net/en/ limnetica) and the maximum likelihood method (Figs. 2a, b and Fig. S2, http://www.limnetica.net/ en/limnetica) were similar for both genes.

In the $12 \mathrm{~S}$ tree (Figs. 2a, S2), the first group belongs to the species $M$. micrura s. str., it includes specimens from terra typica (Nové Dvory, CZ). The specimen sequenced by Petrusek et al. (2004) from a sandpit near Dobřín (CZ) (Supplementary information, Table S1) was grouped together with these, as well as specimens from Slovakia and Israel, in the same way as in the BOLD Id tree (Fig. S1). The closest relative to this clade is $M$. cf. micrura 1 ES from Spain (BIN: ACA1509). The second group forms a consistent cluster and is apparently restricted to Spain (ES). The two next groups which include sequences from Ethiopia (ET) and Australia (AU) are singletons, so further sequencing is needed to assess the distribution and variation within these groups. The fourth group is another species of the micrura-complex (Moina cf. micrura 2 ES), occurring in sympatry with $M$. cf. micrura $1 \mathrm{ES}$ in the Albufera of Valencia lake (Spain). Next cluster groups together a sequence from Hungary (HU) and another from Zahillo pond in the Doñana National Park, South Spain (M. cf. micrura 3 ES).

The COI tree (Figs. 2b, S1), which allowed us to compare sequences from other parts of the world, included eleven groups that were recognized as distinct OTUs by both BIN and ABGD approaches. This wider comparison gave related results (comparable to those of Bekker et al., 2016): the first group is Moina micrura s. str. and include sequences from the Czech Republic and Kazakhstan. The nearest group, as in $12 \mathrm{~S}$ tree, is the cluster represented by the Spanish Moina cf. micrura 1 ES. The remaining nine groups are possibly distinct species, each with a geographically restricted distribution. The regions with Moina micrura s. str., confirmed by our results, are restricted to four: the Czech Republic, nearby Slovakia, Israel and the easternmost record in Kazakhstan.

Molecular analyses thus confirm that Moina micrura s. 1. is a diverse group of species, with $M$. micrura s. str. apparently restricted only to a limited region of the Old World, probably western part of the Palearctic region only. However, before any nomenclatural act is taken to describe all these presumably new cryptic species or resurrect old names at present considered synonymous to $M$. micrura, it is necessary a complete an adequate morphological description of Moina 


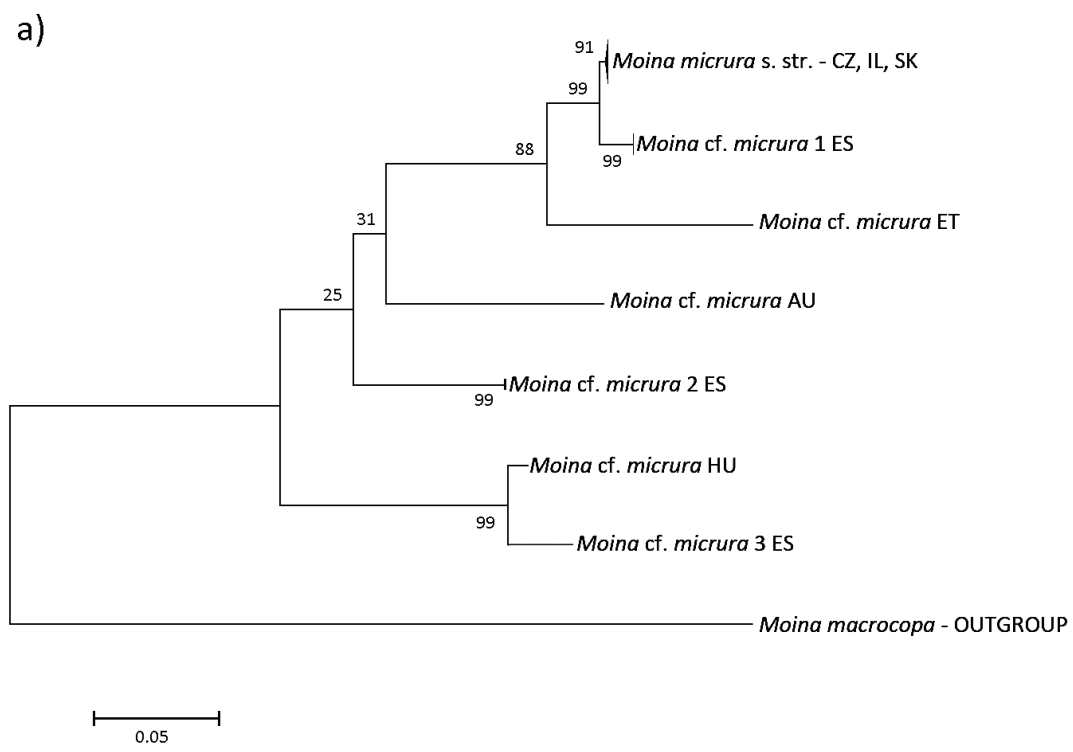

b)

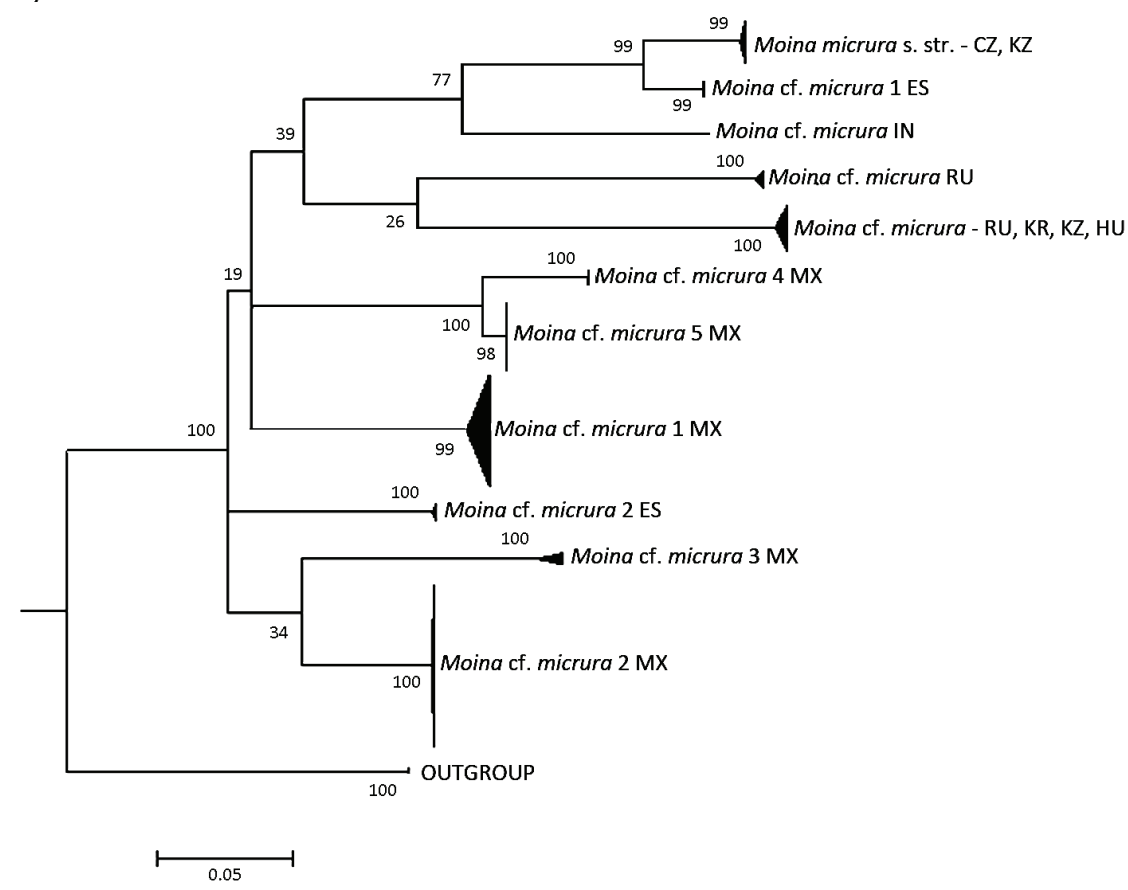

Figure 2. Maximum Likelihood trees of the Moina micrura complex based on analyzed mitochondrial genes. A. Tree based on 29 sequences of $12 \mathrm{~S}$ gene; Moina macrocopa from the Czech Republic was used as an outgroup. B. Tree based on 148 COI sequences from the M. micrura complex; $M$. cf. macrocopa from Mexico was used as an outgroup. Bootstrap values (1000 replicates) are shown above the branches. The scale bar shows K2P distances. The node for each clade with multiple specimens is collapsed. The expanded tree is found as Fig. S4. Árboles de máxima verosimilitud del complejo Moina micrura basado en los genes mitocondriales analizados. A. Árbol basado en 29 secuencias del gen 12S; se usó Moina macrocopa de la República Checa como grupo externo. B. Árbol basado en 148 secuencias del COI del complejo M. micrura; M. cf. macrocopa de México se usó como grupo externo. Se muestran los valores de bootstrap (1000 réplicas) por encima de cada rama. El valor de la barra de escala muestra las distancias K2P. El nodo para cada clado con múltiples especímenes está colapsado. El árbol expandido se encuentra en la Fig. S4. 
micrura s. str. Because of this reason, we provide in the next part a detailed description of M. micrura s. str. from terra typica.

\section{Redescription of Moina micrura Kurz, 1875}

\section{Synonymy uncertain}

Neotype: adult parthenogenetic female from Sádka pond stained with lignin pink and chlorazol black E; mounted in Canada balsam.

Type locality: Czech Republic, fish pond Sádka, at Nové Dvory village, NE of Kutná Hora, $49.963 \mathrm{~N}, 15.329$ E. Repeated sampling from 2002 to 2015 \& laboratory culture of specimens collected in the same pond (A. Petrusek \& M. Miracle legerunt).

- Distribution of specimens from "terra typica" (watershed of the Elbe River in Central Europe) among museums:

- National Museum, Natural history collections, Prague:

1. One permanent mount of a Moina micrura Kurz, 1875 female - neotype specimen. Stained with a mixture of lignin pink \& chlorazol black $\mathrm{E}$ and mounted in Canada balsam. Sádka Pond, Kutná Hora, Nové Dvory. 27.6.2002. A. Petrusek legit. Cat. Nr. P6E 4160

2. Four permanent mounts stained and mounted as above, specimens collected in the same locality. P6E 4161 \& P6E 4162 (zooplankton sample), P6E 4163 (females) and P6E 4164 (males). Laboratory culture.

3. One permanent mount of Moina micrura from Upper Školní Pond, near Chabařovice. 8.8.2004. K. Pilařová legit; stained as above, mounted in Hydro-Matrix synthetic water miscible resin. P6E 4165.

4. One permanent mount of Moina micrura from a sand pit at Dobrrín̆, NE of Roudnice nad Labem. 19.9.1999. A. Petrusek legit. Specimens cleared in hot lactic acid, stained as above, mounted in Canada balsam. P6E 4166.

5. One vial with zooplankton sample from the neotype locality, 27.6.2002, A. Petrusek legit. Preserved in $70 \%$ ethanol. The species Moina micrura predominant, Moina weismanni Ishikawa, 1896 accessory. P6E 4169.
- Natural History Museum UK, London

1. One vial with zooplankton sample from the neotype locality, 27.6.2002. A. Petrusek legit. Preserved in $70 \%$ ethanol. Cat. Nr. NHMUK 2017.38-47

\section{Diagnosis}

\section{Parthenogenetic female}

With round body, dorsum of valves elevated behind head when embryos present, convex or slightly straight in posterior part, no hairs on head and valves. Head with marked supraocular depression, no rostrum; ocellus without pigment. Denticles at posterior margin of valves organized in groups, each group with 7-10 elements increasing in size posteriorly. Postabdomen with row of 4-5 scale-like teeth fringed with row of marginal setae, and bident tooth with distal branch always significantly longer than proximal branch. Row of fine setae at the base of bident. Three groups of denticles and setules (pectens) on outer face of postabdominal claw; basal and middle pectens consisting of 4-5 and 8-12 strong thick spines, respectively, arranged fan-like; distal pecten with fine spinules. Basal and middle pectens often fused in continuous row. Antennule rod-like, with line of long setules on posterior face and sensory seta in middle, groups of minute spines with variable arrangements. Antenna with two coxal sensory setae, one short and other long reaching nearly to top of basal segment. Basal segment with minute distal spine on dorsal face, and remarkably long distal sensory seta on ventral face. Thoracopod I (Th1) with inner distal lobe (IDL) bearing a single strong anterior seta and 2 posterior soft setae. Endite 3 (= "penultimate segment") with anterior seta, endite 1 with three posterior setae and two ejector hooks, one large and other small.

\section{Ephippial female}

Ephippium with one egg. Free ephippium from lateral aspect broadly rounded anteriorly, posteriorly slightly tapering. Ephippium with robust dorsal ridge, its surface covered with hexagonal pattern. 


\section{Male}

Body elongated. Dorsal margin nearly straight or feebly convex. Head small, wedge-like; filled up by optic vesicle. Ocellus without pigmentation. Ventral face slightly convex with antennule inserted laterally. Antennule long, apical sensory setae relatively long, two more setae (male seta and a sensillum) near first third of antennule. Four apical hook-like spines of different sizes. Trunk thoracopod I with a long, curved copulatory hook, its tip with two small claw-like projections and wart-like outgrow near inner base of its curvature. Large basal part of hook rounded and covered with dense mat of short hairs. Postabdomen with row of 4 plumose teeth and bident tooth, length of both branches of bident as in female. Row of fine setae at base of bident. Pectens on dorsal face of postabdominal claw as in female. Group of three oblique denticles near base of claw on the ventral side. Lateral gonopores situated on each side of postabdomen close to respective proximal-most plumose teeth.

\section{Detailed description}

\section{Adult parthenogenetic female (Fig. 3A)}

Length: $0.44-0.76 \mathrm{~mm}(\mathrm{n}=25)$. Body nearly rounded in lateral aspect, high (body height to length ratio 0.54-0.68), maximum height in middle-posterior portion, depending on number of embryos. Dorsum of valves strongly convex, projected much higher than head, almost straight in posterior part, dorsal depression between head and rest of body present. Postero-dorsal angle well-marked, rounded. Posterior margin more or less straight, continuing into widely convex ventral margin. No sculpture on surface of valves. No cuticular hairs on head and valves, without dorsal keel. Live animals are whitish in color.

Head - relatively large, rounded, without any rostral projection; with marked supra-ocular depression and large compound eye. Optical vesicle contiguous with prominent top of head. Ventral margin depressed under compound eye and bulging at level of antennules. Ocellus without visible pigmentation or with few grains of pigment (Fig. 3A).
Labrum - with fleshy main body, its ventral margin slightly convex.

1st maxilla - with three long strongly curved setae and one short stump-like outgrow, all with secondary setules.

Mandible - with asymmetrical, bifurcated anchoring projection.

Antennule (A1) - rod-like, about four times longer than wide, almost cylindrical, with transverse rows of scattered denticles on anterior face and row of long setules on posterior face (Fig. 3P). Antennular sensory seta conical, elongated, arising approximately in middle of lateral face. Distal tip bordered with small thick spinules. Nine short aesthetascs, two of them slightly longer. Tip of each aesthetasc with small projections giving an aspect of crown.

Antenna (A2) - similar in parthenogic and ephippial female. Coxal part with two setulated sensory setae, one long reaching up to $3 / 4$ of basal segment length, the other short and thin (Fig. 3N, arrows). Basal segment robust, with distal spine at dorsal face as long as first segment of 4-segmented antennal branch (Fig. 3O, magnification); long distal sensory seta on ventral face (Fig. 30, arrow). Transverse rows of numerous, minute spinules on surface. Antennal branches elongated, 4-segmented exopodite slightly shorter than 3 -segmented endopodite, all segments cylindrical, with rows of minute spinules and rows of long and thin setae. Antennal formula: setae $0-0-1-3 / 1-1-3$, spines $0-1-0-1 / 1-0-1$. Three long, apical swimming setae on both antennal branches, all with basal and distal segments bilaterally armed with fine, long setules. Lateral seta on third segment of dorsal branch with similar armature. Basal and distal lateral setae of ventral branch armed in another manner: basal segments unilaterally setulated and distal ones asymmetrically setulated. Spine on first endopodite segment short, like apical spines.

Valves - large, sub-ovoid, with row of 14 to16 setae along anterior ventral margin. Posterior part with row of marginal denticles, organized in groups of 7-10, increasing in size distally within each group. Denticles in posterior most margin form uniform row. Two posterior hooks supporting postabdominal setae (setae natatoriae) present. 

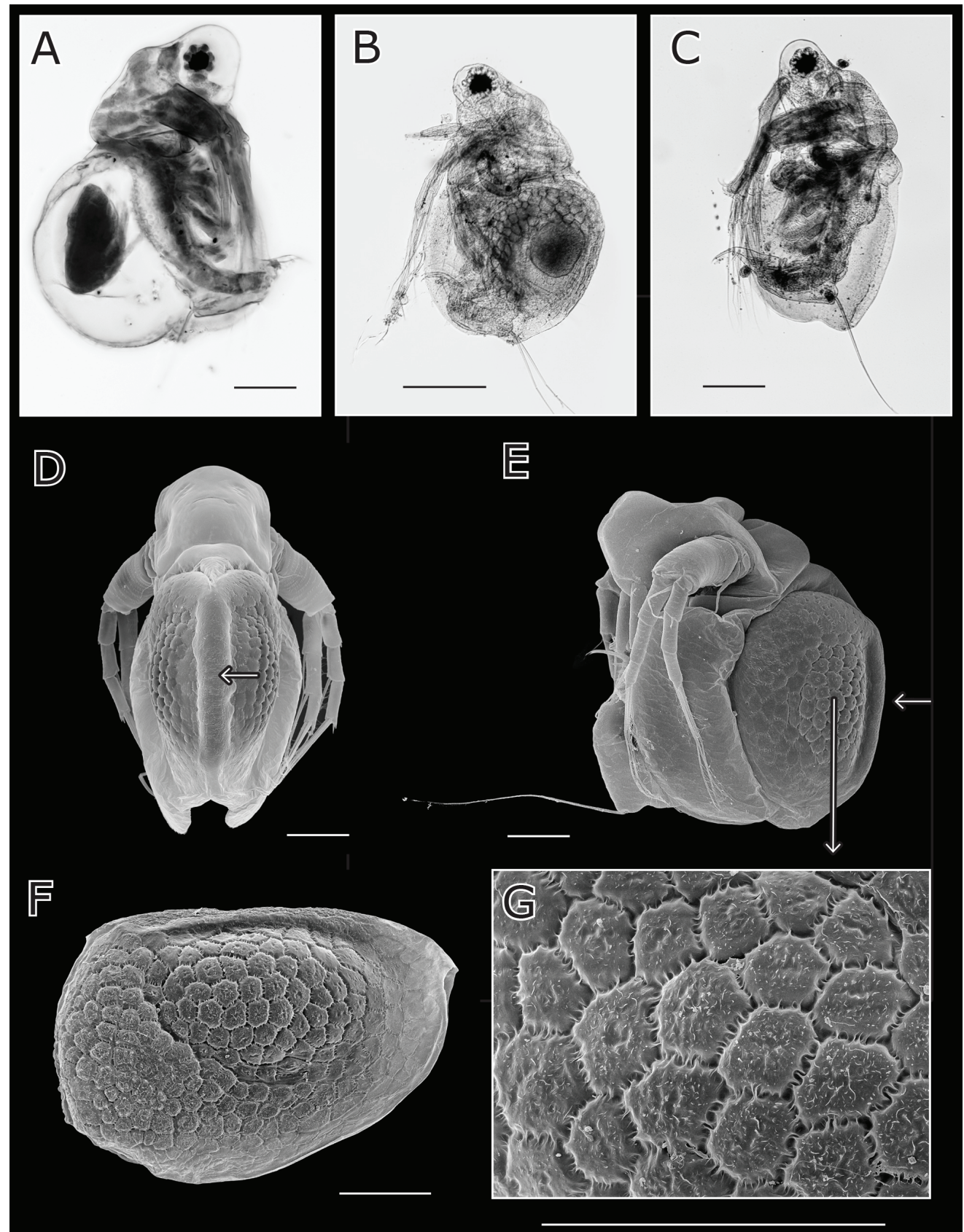

Figure 3. Morphological features of Moina micrura s. str. Specimens were sampled at three localities in the Czech Republic: fishpond Sádka at Nové Dvory (27.06.2002, images A, B, C, F, G, I, Q, R, S, T, U \& V); fishpond Školní at Chabařovice (2.08.2004, images D, E, H, J, K, L, M, N \& O), and flooded sandpit near Dobřín (5.10.1999, image P). A-C: light microscope, focus stacked images. A) Adult parthenogenetic female. B) Adult ephippial female. C) Adult male. D-R: SEM. D) Adult ephippial female in dorsal view, dorsal ridge indicated by arrow. E) Adult ephippial female in lateral view, dorsal ridge indicated by arrow. F) Free ephippium in lateral view. G) Ultrastructure of free ephippium. Características morfológicas de Moina micrura s. str. Especímenes recolectados de tres localidades de la República Checa: el estanque de peces Sádka en Nové Dvory (27.06.2002, imágenes A, B, C, F, G, I, Q, R, S, T, Uy V); estanque de peces Školni en Chabařrovice (2.08.2004, imágenes D, E, H, J, K, L, M, N y O), y arenal inundado cerca de Dobřin (5.10.1999, imagen P). A-C: microscopio óptico, con las imágenes apiladas. A) Hembra partenogenética adulta. B) Hembra efipial adulta. C) Macho adulto. D-R: SEM. D) Hembra efipial adulta en la vista dorsal, cresta dorsal indicada por una flecha. E) Hembra efipial adulta en vista lateral, cresta dorsal indicada por una flecha. F) Efipio libre en vista lateral. G) Ultraestructura del efipio libre. 


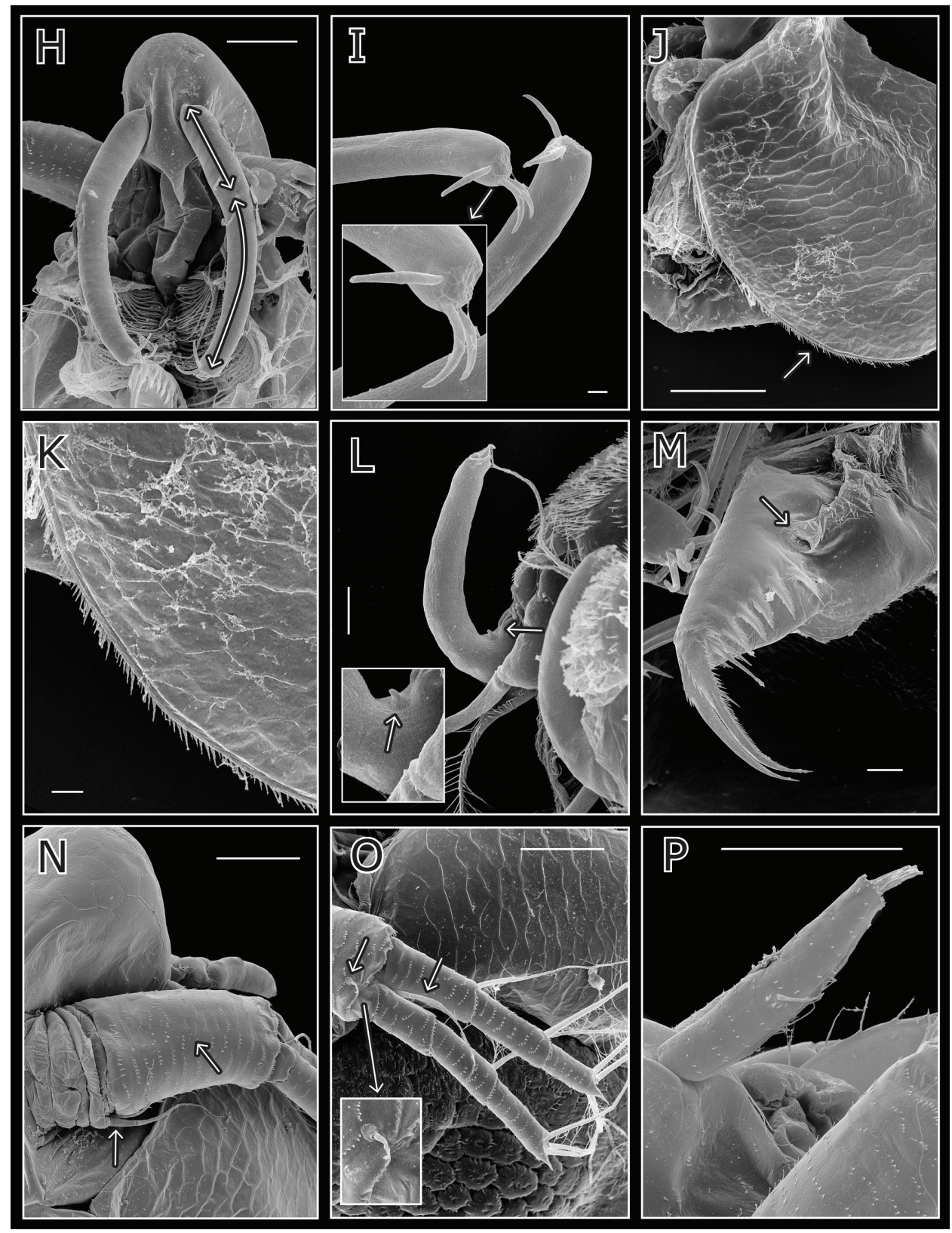

Figure 3 (cont.). H) Adult male, head in the ventral view. Arrows highlight proportion of proximal and distal antennular parts. I) Adult male, tips of antennules (detail). J) Adult male, ventral carapace margin. Arrow indicates spines along posterior ventral margin. K) Magnified detail of the spines along posterior ventral margin (as in previous image). L) Adult male, 1st thoracopod, arrows indicate small outgrow at base of the hook and its detail in the inset. M) Adult male postabdomen, arrow indicates gonopore. N) Ephippial female, basipodite of antenna. Arrows point to arrangement of minute spines on its surface and two sensory setae at its base. O) Ephippial female, antenna - arrows indicate the apical dorsal spine and ventral seta of the basipodite. P) Adult female, antennule. H) Macho adulto, cabeza en vista ventral. Las flechas resaltan la proporción de partes antenulares proximales y distales. I) macho adulto, puntas de las anténulas (detalle). J) Macho adulto, margen del caparazón ventral. La flecha señala las espinas a lo largo del margen ventral posterior. K) Detalle de las espinas a lo largo del margen ventral posterior (como en la imagen anterior). L) Macho adulto, primer toracópodo. Las flechas indican una pequeña protuberancia en la base del gancho y su detalle en el recuadro. M) Macho adulto, postabdomen, la flecha indica el gonoporo. N) Hembra efipial, basipodito de la antena. Las flechas apuntan a la disposición de diminutas espinas en su superficie y dos setas sensoriales en su base. O) Hembra efipial, antena: las flechas indican la espina dorsal apical y la seta ventral del basipodito. P) Hembra adulta, primera anténula. 


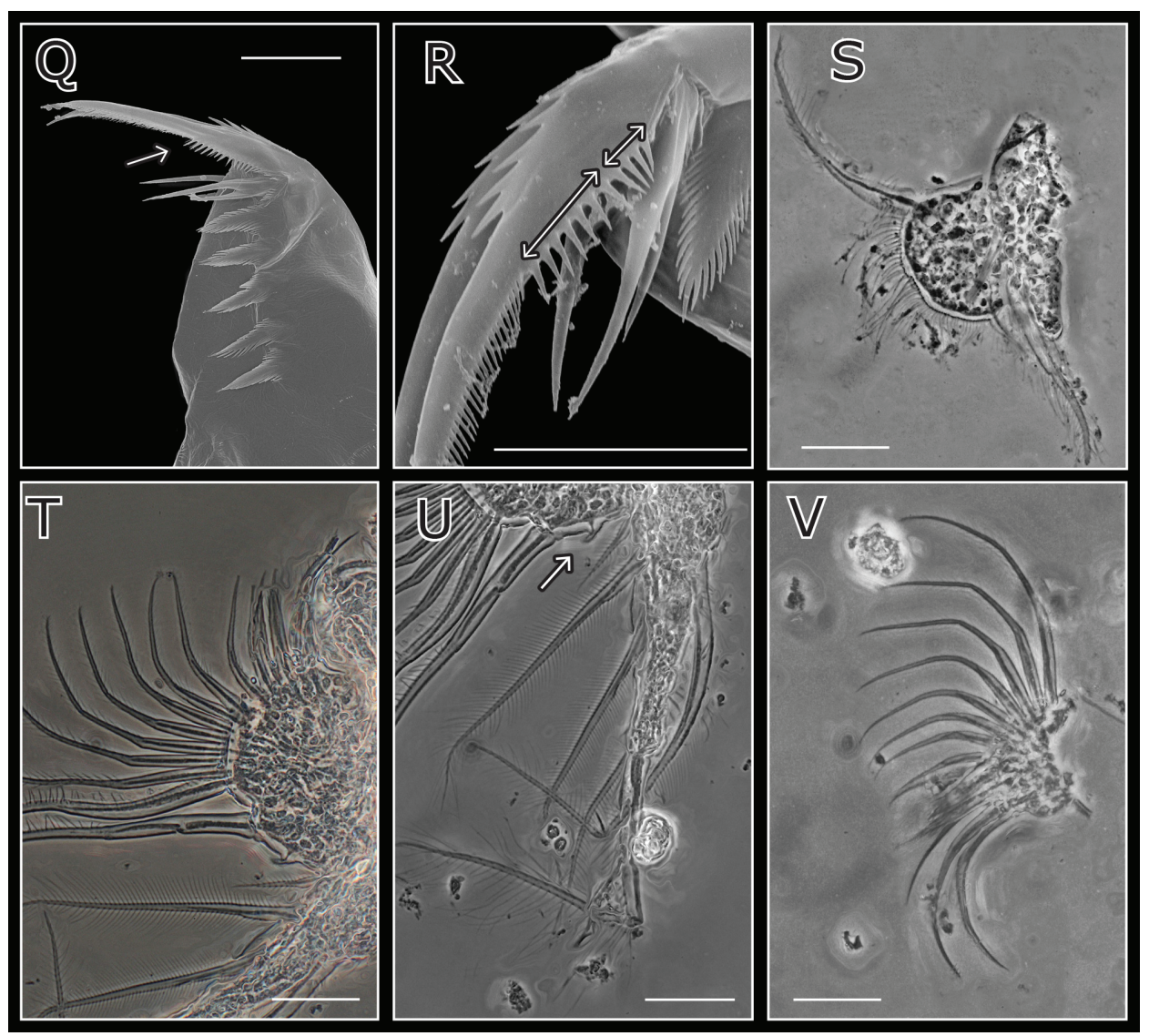

Figure 3 (cont.). Q) Adult female, postabdomen, arrow indicates the middle pecten. R) Adult female, base of postabdominal claw with three dorsal pectens (proximal and middle indicated by arrows) and group of robust ventral teeth. S) Adult female, 5th thoracopod. T) Adult female, 2nd thoracopod. U) Adult female, exopod in 2nd thoracopod. V) Adult female, 2nd thoracopod gnathobase. Scale bars indicate $0.1 \mathrm{~mm}(\mathrm{~A}-\mathrm{G}, \mathrm{J}), 10 \mu \mathrm{m}(\mathrm{K}-\mathrm{M}, \mathrm{Q}, \mathrm{R}), 5 \mu \mathrm{m}(\mathrm{H}, \mathrm{N}, \mathrm{P})$ and $25 \mu \mathrm{m}(\mathrm{S}-\mathrm{V})$. Q) Hembra adulta, postabdomen, la flecha indica el pecten medio. R) Hembra adulta, base de la garra posabdominal con tres peines dorsales (proximal y medio indicados por flechas) y un grupo de dientes ventrales robustos. S) Hembra adulta, quinto toracópodo. T) Hembra adulta, segundo toracópodo. U) Hembra adulta, exópodo del segundo toracópodo. V) Hembra adulta, gnatobase del segundo toracópodo. Las barras de escala indican $0.1 \mathrm{~mm}$ $(A-G, J), 10 \mu m(K-M, Q, R), 5 \mu m(H, N, P)$ y $25 \mu m(S-V)$.

\section{Thoracopods (Th)}

Th1 (Fig. 4A) - distal lobe or endite 4 with single anterior thicker setulated seta, and two soft setae. Endite 3 with short, strong, single anterior seta (arrow), bearing noticeable lateral spinules-like projections in both sides, and single long and strong posterior seta. Endite 2 with two posterior setae. Endite 1 with three posterior setae. Two ejector hooks of remarkably different sizes. No maxillary process on limb base.

Th2 (Figs. 4B-D) - with large cylindrical lobe bearing long apical seta, its distal part regularly setulated. Distal endite with two setulated setae, other two endites with only one setulated seta each. One small seta near gnathobase plate (Fig. 3T, Fig. 4B, D, I), followed anteriorly by small hook-like outgrow (arrow in Fig. 3U, Fig. 4D: se). Rest of gnathobase margin with row of setae arranged fan-like (Fig. 3V). A long beating seta (see Kotov et al., 2005) and a neighboring more anteriorly located, long seta (1 in Fig. 4B) separated by large gap (Fig. 3T). Both unilaterally setulated with long peg-like setules facing proximally. After these two long setae are a row of 10 to 12 gradually shortening and curved filter setae, 
with a fan-like arrangement (a-1 in Fig. 4B). This group of setae is closed by a group of three anterior setae, inserted in the basal corner of the gnathobase (Fig. 4C: 2-4). , curved proximally, one with unilateral setulation facing distally (Fig. 4C: 4), and two more reduced brush-like (Fig. 4C: 2-3).
Th3 - exopodite large, flat, with four distal setae (c-f in Fig. 4E) and two short proximal setae, one short and one long (a and b in Fig. 4E), all of them bilaterally setulated. Inner distal portion with three endites. Endite 3 with single anterior seta (3 in Fig. 4E); endite 2 with one
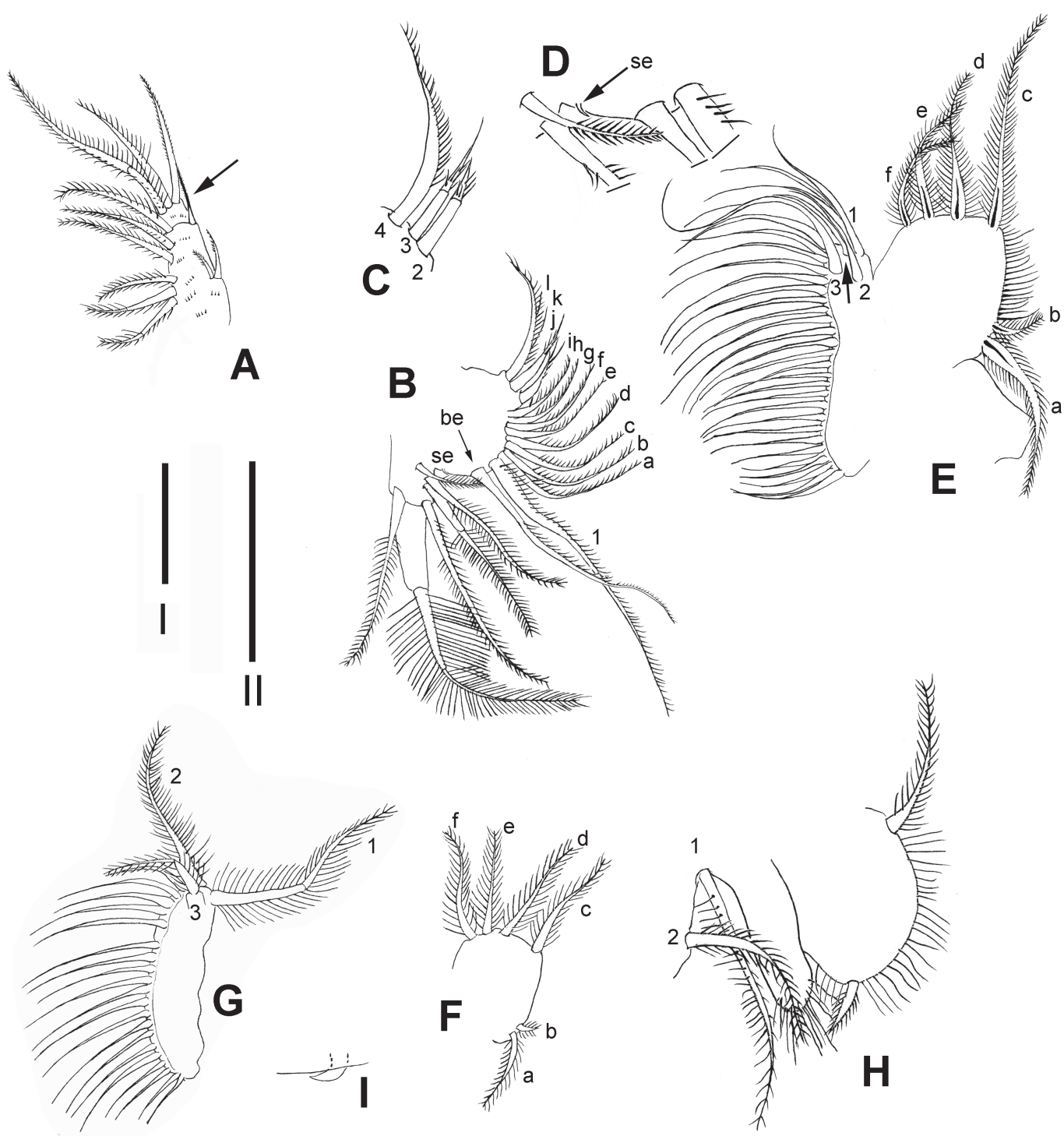

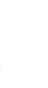


anterior and one posterior seta (2, and arrow in Fig. 4E). Endite 1, with one anterior seta (1, in Fig. 4E). Rest of endopodite with 28-29 soft setae (Fig. 4E).

Th4 (Figs. 5G) - exopodite like Th3, but more elongated (Fig. 4F), with four long setae (c-f in Fig. 4F) in distal part and two setae in proximal part, one short and other long (a-b in Fig. 4F). Inner distal portion of thoracopod with two endites: endite 1 with long articulated and bisetulated seta (1 in Fig. 4G). Endite 2 with two long setulated setae (2, 3 in Fig. 4G). Filter plate with 20-22 setae (Fig. 4G).

Th5 - with large ovoid lobe, with setulated margin, large distal seta and small proximal seta, both bi-setulated (Fig. 3S and 4H). Inner thoracopod portion with elongated lobe with long setulae followed by two setae (1-2 in Fig. 4H).

Postabdomen - elongated, conically narrowing distally. Ventral margin almost straight, with numerous rows of minute setules in transversal rows (Fig. 3Q). Large anus located closer to base of postabdomen than to its distal extremity, preanal margin long, straight. Post-anal part tapering to claws. Preanal angle not well expressed. Laterally, row of 4-5 large, triangular teeth, fringed with marginal setules. Rows of setules on distal portion continue along base of bident tooth; distal branch of bident tooth significantly longer than proximal branch.

Setae natatoriae longer than postabdomen; basal part naked, distal part with two rows of fine setules (Fig. 1).

Postabdominal claw slightly curved, with sharp, pointed tip (Fig. 3Q, R). Three successive pectens along dorsal margin: basal pecten consisting of 4 to 8 slender spines huddled together, followed by middle pecten of 7-12 strong, thick spines; distal pecten consisting of smaller spines forming row from mid-claw to naked tip (Fig. 3Q: arrow). Basal and middle pectens fused in some individuals. Uniform row of spinules along inner face of claw. 4-7 large denticles on ventral margin, near base of claw.

\section{Ephippial female (Figs. 3B, D-G)}

Ephippium broadly rounded, tapering only slightly in posterior part. Central part over egg chamber embossed. Dorsal ridge strongly sclerotized (Fig. 3D: arrow, 3E: right arrow). Lateral surface with marked hexagonal reticulated pattern (Fig. 3F, G). Ultrastructure of ephippial surface (magnification up to $1000 \mathrm{x}-2000 \mathrm{x}$ ) formed by complex structure of polygons interlocked with many thin tentacle-like projections of various length. Some projections cover also inner surface of polygons (Fig. 3G).

\section{Male (Fig. 3C, 3H-M)}

Body - smaller than female, body length $0.45-0.54 \mathrm{~mm}(\mathrm{n}=10)$, more elongated as compared to female (Fig. 3C). Dorsal margin of valves almost straight, postero-dorsal angle clearly distinct. Antero-ventral portion of valves fringed with long, thin setules. Denticles along posterior margin more distinct than in female, arranged in groups (Fig. 3J: arrow, 3K).

Head - more elongated than in female, rostrum absent, labrum less fleshy than that of female. Optical vesicle fills top of head. No trace of pigment in ocellus.

Antennule - long, antennular sensory seta relatively long, male seta and sensillum inserted in first third of antennule (Figs. 3H). Nine aesthetascs and three to four hooks of distinct size and orientation, with bifurcated tips, present distally (Figs. 3I).

Antenna - similar in armature to female. Distal margin of all segments with row of thick, short spinules.

Carapace surface without any hairs or setules (Fig. 3J).

Th1 - with thick copulatory hook, its tip with two spinules, endite 4 (IDL) with three setae, endite 3 with one seta. Basal part short and rounded (width: length ratio about 1:1), with row of stout bristles on ventral face (Figs. 3L). Small wart-like outgrow at inner base of hook (Fig. 3L, arrow).

Postabdomen - as in female, shorter, with about 4-5 setulated teeth, distalmost tooth thin and with sharp tip (Fig. 3M). Distal bident tooth as in female. About 4-5 teeth in basal pecten of postabdominal claw, up to 10 in middle pecten (arranged fan-like) and 5-7 on ventral side at basal part of claw. Gonopores in lateral position 

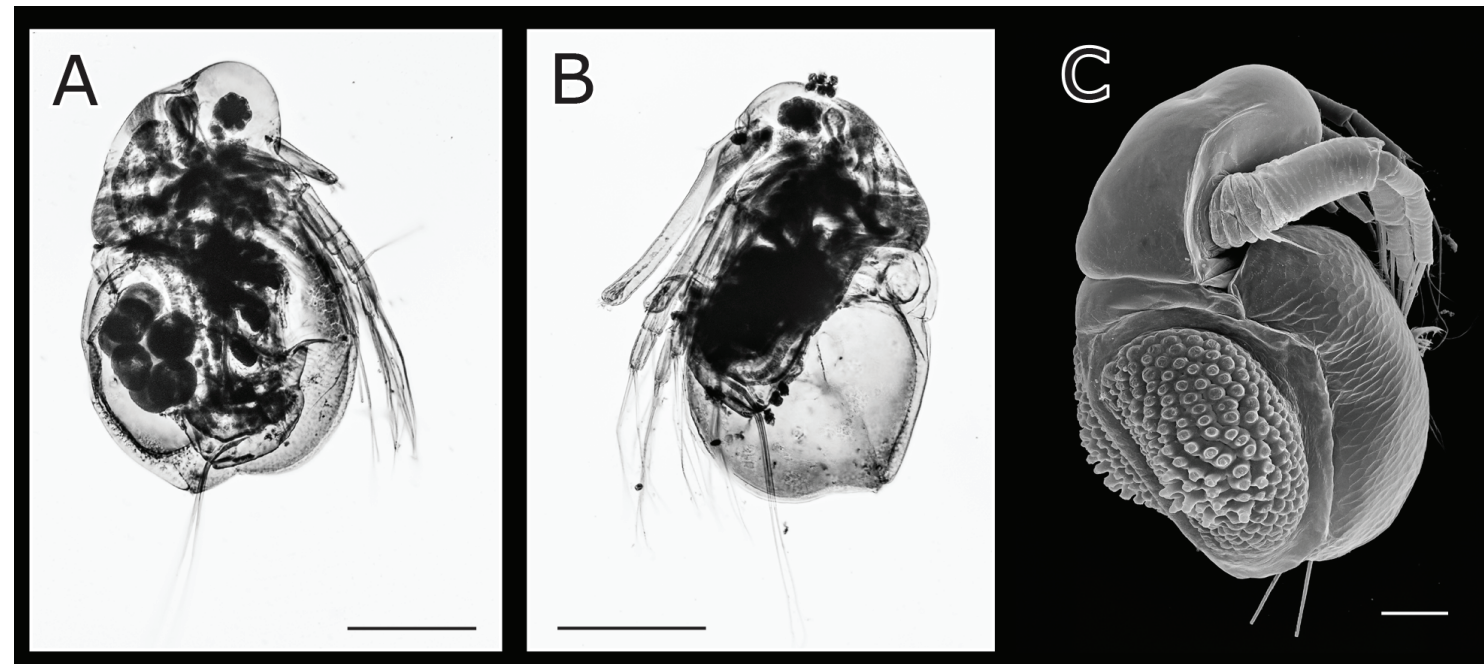

D

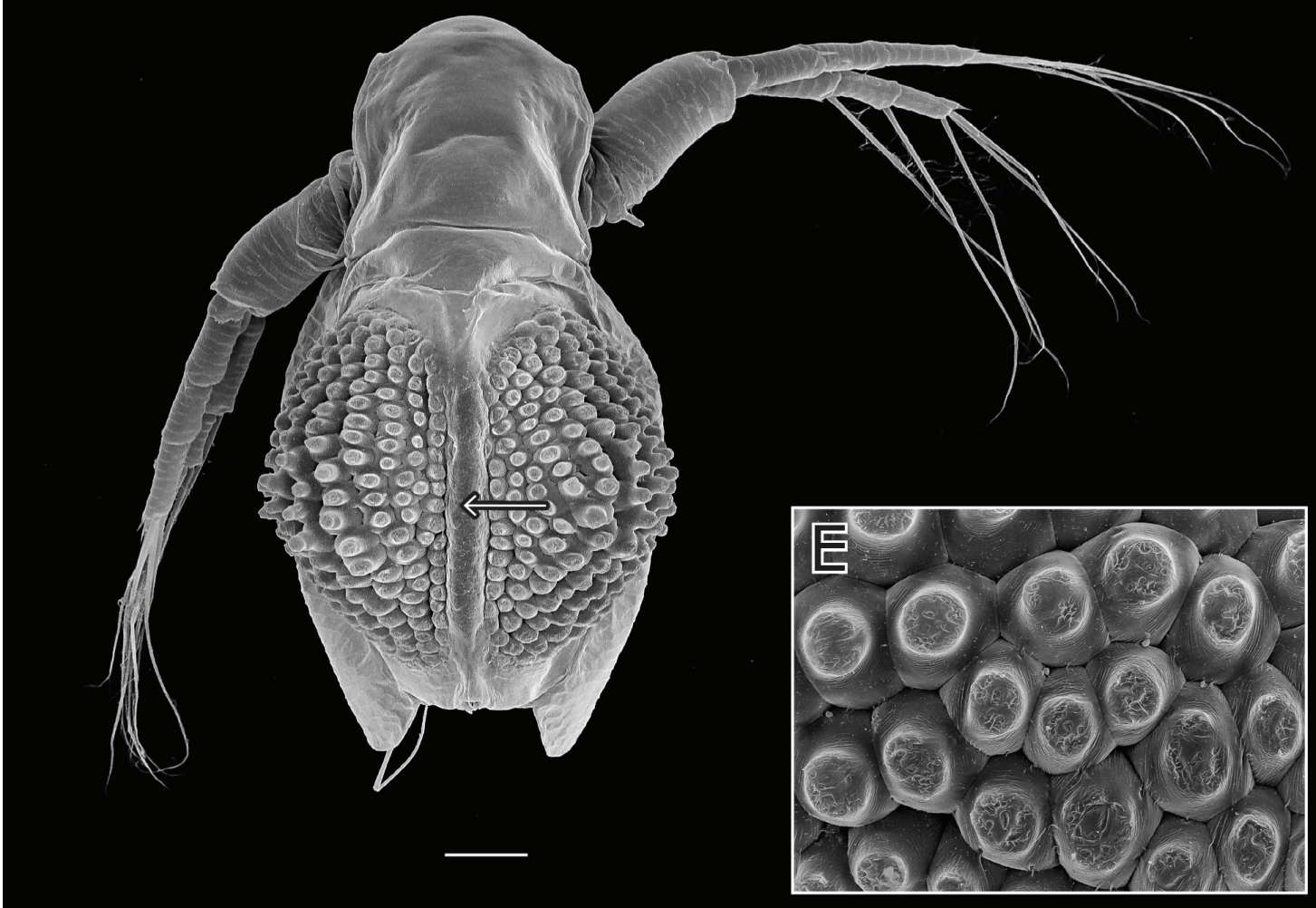

Figure 5. Morphological features of Moina weismanni. Specimens sampled at Radíkovice, Czech Republic (03.07.1957, images A \& B) and at Krasnodar, Russia (21.07.1952, all other images). A-B: light microscope, focus stacked images. A) Adult female in lateral view. B) Adult male in lateral view. C-M: SEM. C) Adult ephippial female in lateral view. D) Ephippial female in dorsal view. Dorsal ridge marked with arrow. E) Ephippium ultrastructure. Características morfológicas de Moina weismanni. Muestras recolectadas en Radikovice, República Checa (03.07.19573, julio de 1957, imágenes A y B) y en Krasnodar, Rusia (21.07.195221 de julio de 1952, todas las demás imágenes). A-B: microscopio óptico, imágenes apiladas. A) Hembra adulta en la vista lateral. B) Macho adulto en la vista lateral. C-M: SEM. C) Hembra efipial adulta en vista lateral. D) Hembra efipial en vista dorsal. La flecha señala la cresta dorsal. E) Ultraestructura del efipio. 

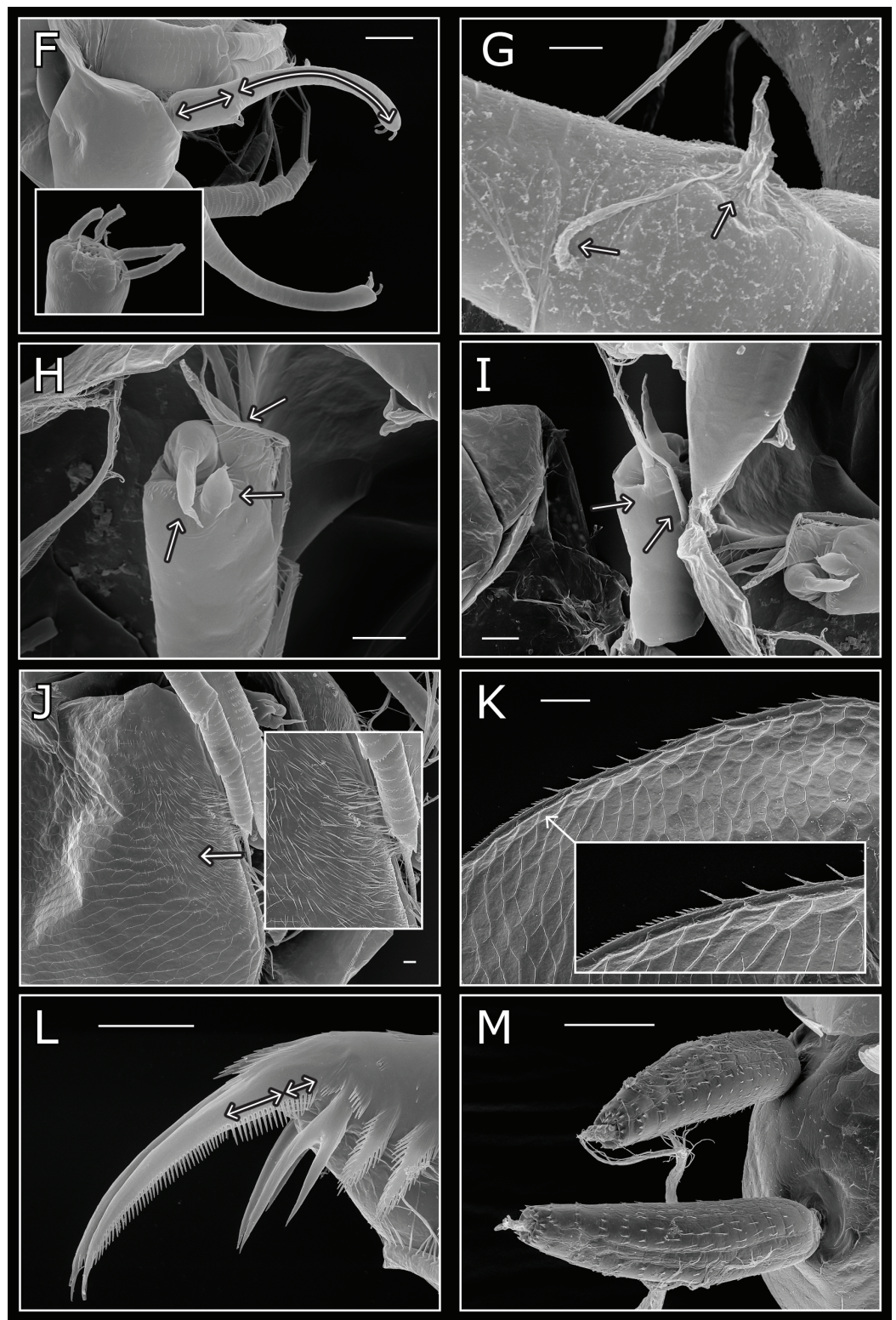

Figure 5 (cont.). F) Adult male, antennule (detail of tips in inset). Arrows show the proportion of the antennular proximal and distal parts. G) Adult male, sensory setae inserted in the first quarter of the antennule length; see arrows. H) Adult male, first thoracopod, ventral aspect. Left arrow marks small copulatory hook, middle arrow marks broad scale-like seta, and top right arrow the thick and naked seta in the background. I) Adult male, first thoracopod in dorsal aspect. Upper arrow indicates thick seta; lower arrow points the lateral seta, J) Adult male, carapace with short hairs. Detail shown in inset. K) Adult female, carapace ventral margin. Detail shown in inset. L) Adult female, postabdominal claw. Arrows indicate - proximal and middle pecten of dorsal slender teeth. M) Adult female, first antennae. Scale bars indicate $0.1 \mathrm{~mm}(\mathrm{~A}-\mathrm{E})$ and $10 \mu \mathrm{m}(\mathrm{F}-\mathrm{M})$. F) Macho adulto, primera antena (detalle de las puntas en el recuadro). Las flechas muestran la proporción de las partes proximal y distal de la anténula. G) Macho adulto, setas sensoriales, insertadas en el primer cuarto de la anténula (ver flechas). H) Macho adulto, primer toracópodo, aspecto ventral. La flecha izquierda marca un pequeño gancho copulatorio, la flecha del medio - marca una seta con aspecto de escama, y la flecha de arriba a la derecha señala la seta gruesa y desnuda en el fondo. I) Macho adulto, primer toracópodo, aspecto dorsal. La flecha superior indica la seta gruesa, la inferior señala la seta lateral, J) Macho adulto, caparazón con pelos cortos. El detalle se muestra en el recuadro. K) Hembra adulta, margen ventral del caparazón. El detalle se muestra en el recuadro. L) Hembra adulta, garra postabdominal. Las flechas indican los pecten dorsales proximal y medio con dientes finos. M) Hembra adulta, primera antena. Las barras de escala indican $0.1 \mathrm{~mm}(A-E)$ y $10 \mu \mathrm{m}(F-M)$. 
Table 2. Differential diagnosis between Moina micrura Kurz and Moina weismanni Ishikawa. Diagnosis diferencial entre Moina micrura Kurz y Moina weismanni Ishikawa.

\begin{tabular}{|c|c|c|c|c|}
\hline Character & Moina micrura & Fig. & Moina weismanni & Fig. \\
\hline \multicolumn{5}{|l|}{ Female } \\
\hline Shape of antenna I. & straight & $4 \mathrm{P}$ & curved & $6 \mathrm{M}$ \\
\hline $\begin{array}{l}\text { Spines in middle } \\
\text { pecten on } \\
\text { postabdominal claw }\end{array}$ & short, robust; $1: 4 *$ ) & $4 \mathrm{R}$ & long, slender; $1: 11-12 *$ ) & $6 \mathrm{~L}$ \\
\hline Ephippial surface & reticulated & $4 \mathrm{~F}, \mathrm{G}$ & distinctly raised knobs & $6 \mathrm{C}, \mathrm{D}, \mathrm{E}$ \\
\hline $\begin{array}{l}\text { Ephippial } \\
\text { ultrastructure } \\
(\mathrm{SEM})\end{array}$ & $\begin{array}{l}\text { polygons interlocked with } \\
\text { many tentacle-like projections }\end{array}$ & $4 \mathrm{G}$ & $\begin{array}{l}\text { distinct knobs } \\
\text { without projections }\end{array}$ & $6 \mathrm{E}$ \\
\hline \multicolumn{5}{|l|}{ Male } \\
\hline $\begin{array}{l}\text { Anterior surface } \\
\text { of carapace }\end{array}$ & Naked & $4 \mathrm{~J}$ & $\begin{array}{l}\text { covered with dense } \\
\text { "fur" of short hairs }\end{array}$ & $6 \mathrm{~J}$ \\
\hline $\begin{array}{l}\text { Length of basal part } \\
\text { of the } 1 \text { st antenna }\end{array}$ & about $1 / 3$ of its length & $4 \mathrm{H}$ & About $1 / 4-1 / 5$ of its length & $6 \mathrm{~F}$ \\
\hline $\begin{array}{l}\text { Setae along anterior } \\
\text { ventral margin }\end{array}$ & about same length & & growing in length distally & \\
\hline \multirow[t]{3}{*}{$1^{\text {st }}$ thoracopod } & $\begin{array}{l}\text { short basal part } \\
\text { (without hook); } 1: 1 * \text { ) }\end{array}$ & $4, \mathrm{~L}$ & long basal part; $1: 2 *)$ & $6 \mathrm{H}, \mathrm{I}$ \\
\hline & hook robust & $4 \mathrm{~L}$ & hook feebly developed & $6 \mathrm{H}$ \\
\hline & $\begin{array}{l}\text { small outgrow at } \\
\text { base of hook }\end{array}$ & $4 \mathrm{~L}$ & $\begin{array}{l}\text { broad scale-like } \\
\text { seta at base of hook }\end{array}$ & $6 \mathrm{H}$ \\
\hline
\end{tabular}

* Ratio widthlength (width of spines in pecten measured at their base) 
situated close to proximal triangular tooth (Fig. $3 \mathrm{M}$, arrow).

\section{Differential diagnosis}

Within terra typica, the species Moina micrura may be confused probably with only one other species: Moina weismanni Ishikawa, 1896 (Figs. $5 \mathrm{~A}-\mathrm{D})$. Both species frequently co-occur in the same habitats and their parthenogenetic females look superficially similar. The list of easily recognized individual characters which differentiate $M$. weismanni from M. micrura is provided in Table 2. Full differential diagnosis from other members of the micrura-like species complex requires detailed systematic revision of populations from other biogeographic regions and the lineages detected by molecular methods.

\section{Intercontinental and interspecific comparison of Moina ephippial ultrastructure}

Specific ultrastructure on the ephippial surface from the terra typica (Fig. 3G), irregular hexagonal pillow-like cells, observed on the material from the Sádka pond, is morphologically similar to the structure observed on the material from other European localities (see Supplementary information, Table S2). However, we did not observe such structure on any of the M. micrura s. 1. material from Africa, Asia, South America or Australia (Fig. 6A-H), whose ephippial structures vary from very flat hexagonal porous patterns (e.g., Figs. 7C, H) to well-delineated polygonal shapes (Fig. 6G). Ephippial ultrastructure of other Moina species (Fig. 7A-H) was even more variable, ranging from almost smooth surfaces (Figs. $7 \mathrm{~A}, \mathrm{~B}$ ) to rounded cells (Figs. $7 \mathrm{G}, \mathrm{H}$ ) or even prominent protuberances (Fig. 5D-E).

\section{DISCUSSION}

Moina micrura has been one of the most poorly defined cladoceran species, recorded under that name in almost any part of the world from the temperate regions to the tropics. Even worse, animals identified as $M$. micrura have been widely used as models for culturing or as ecotoxicology biomarkers. Results of studies employing this taxon, however, cannot be directly compared or replicated, as mentioned in the introduction. There was thus an urgent need to establish the correct assignment for $M$. micrura as a valid species, including the neotype, genetic analyses and detailed morphological description of all forms within the life cycle.

According to the International Code of Zoological Nomenclature (International Commission on Zoological Nomenclature 1999), designation of a neotype is justified when there is an exceptional need to clarify the taxonomy of a species (as is the case when several poorly defined sibling species exist), or when there is a reasonable certainty that the original type material does not exist. In case of M. micrura, both these conditions are met. Our search for the type material of M. micrura was unsuccessful. Kurz's original samples or specimens are not available either in the National Museum, Prague (curator's personal communication, P. Dolejš, 2014) or in Naturhistorisches Museum, Wien (curator P. Dworschak, 2015), which would be most likely institutions for depositing types of animal species described in the 19th century from Bohemia.

Considering the documented existence of several genetically well-defined lineages, so far labelled as Moina micrura, it is necessary to establish the neotype and the new type locality as a reference for future studies. We chose the new type locality as close as possible from the original one studied by Kurz (1875). However, typical $M$. micrura localities in terra typica, the watersheds of the Elbe and Danube rivers, are fish ponds and other relatively small water bodies with rapidly changing environments. Therefore, it is highly probable that many present-day Moina populations will disappear or re-occur in the near future. Hence, we added some more localities from terra typica as a comparative material.

Despite rapidly changing natural environments of Europe, we managed to collect $M$. micrura no more than $10 \mathrm{~km}$ from the Kurz's original type locality. Petrusek et al. (2004) used material located about $90 \mathrm{~km}$ from the locus typicus; to confirm the conspecifity of our population we sequenced the gene for $12 \mathrm{~S}$ rRNA originally studied by Petrusek et al. (2004). Both studied Czech populations indeed belonged to the 

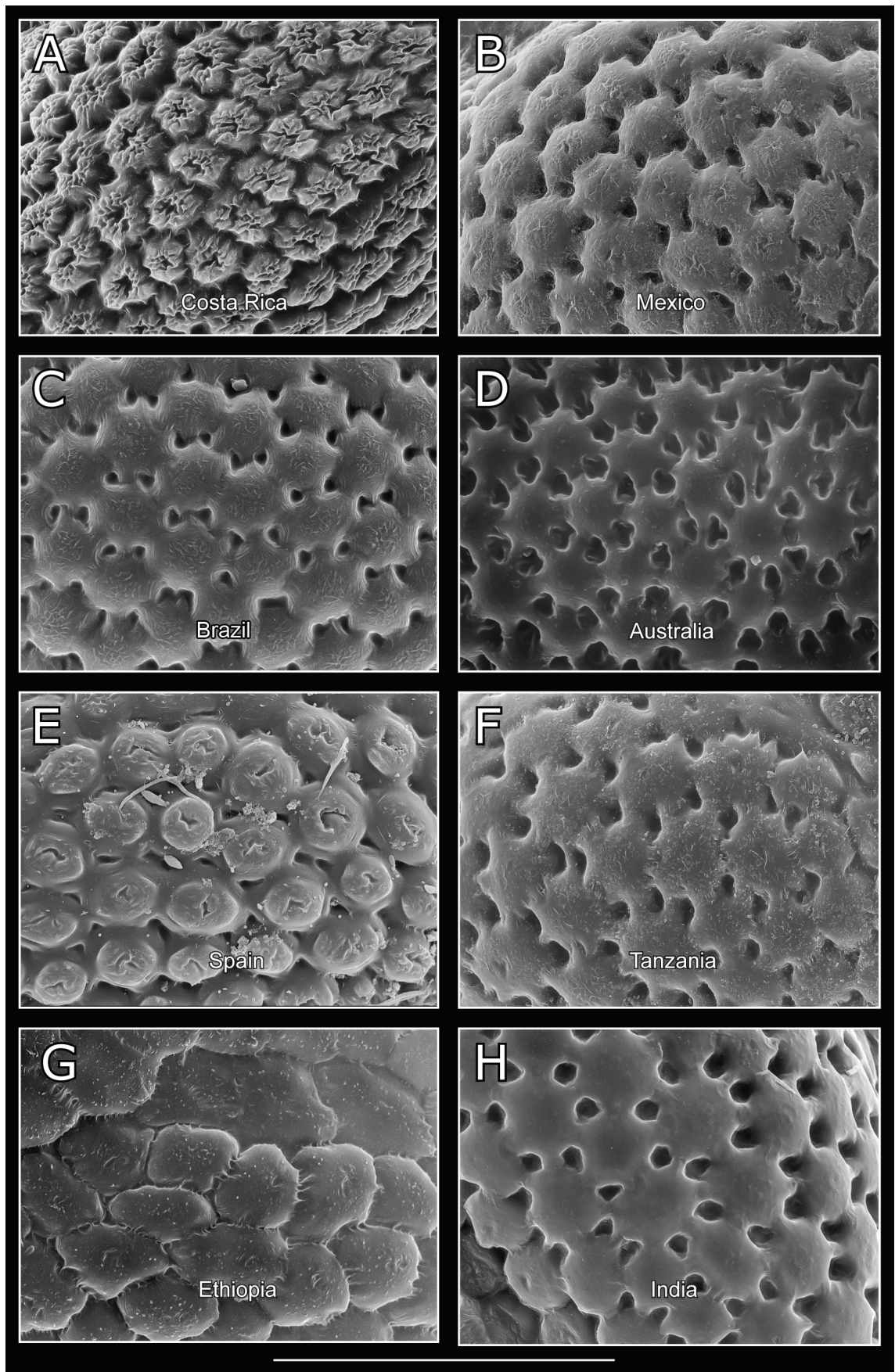

Figure 6. Intercontinental comparison of ephippial ultrastructure of Moina micrura s. 1. Ephippia were mostly positioned in the ephippial female. All images are of the same magnification. A) Costa Rica (18.05.1981). B) Bordo La Colorada, Aguascalientes, Mexico (18.01.1989). C) Lima, Lima Campos, Ceara, Brazil (23.05.1989). D) Relfs, NSW, Australia (25.01.1968). E) Lake Albufera, Valencia, Spain (2015). F) Mwanza, Tanzania (07.04.1985). G) Borena, Oromia, Ethiopia (01.10.1983). H) Jabaddi Ludhiana, Punjab, India (13.09.1977). Scale bar indicates $0.1 \mathrm{~mm}$ for all photographs. Comparación intercontinental de la ultraestructura efipial de Moina micrura s. l. Los efipios se tomaron principalmente en la hembra. Todas las imágenes son con la misma magnificación. A) Costa Rica (18.05.1981). B) Bordo La Colorada, Aguascalientes, México (18.01.1989). C) Lima, Lima Campos, Ceara, Brasil (23.05.1989). D) Relfs, NSW, Australia (25.01.1968). E) Albufera de Valencia, España (2015). F) Mwanza, Tanzania (07.04.1985). G) Borena, Oromia, Etiopía (01.10.1983). H) Jabaddi Ludhiana, Punjab, India (13.09.1977). La barra de escala indica 0.1 mm para todas las fotografias. 


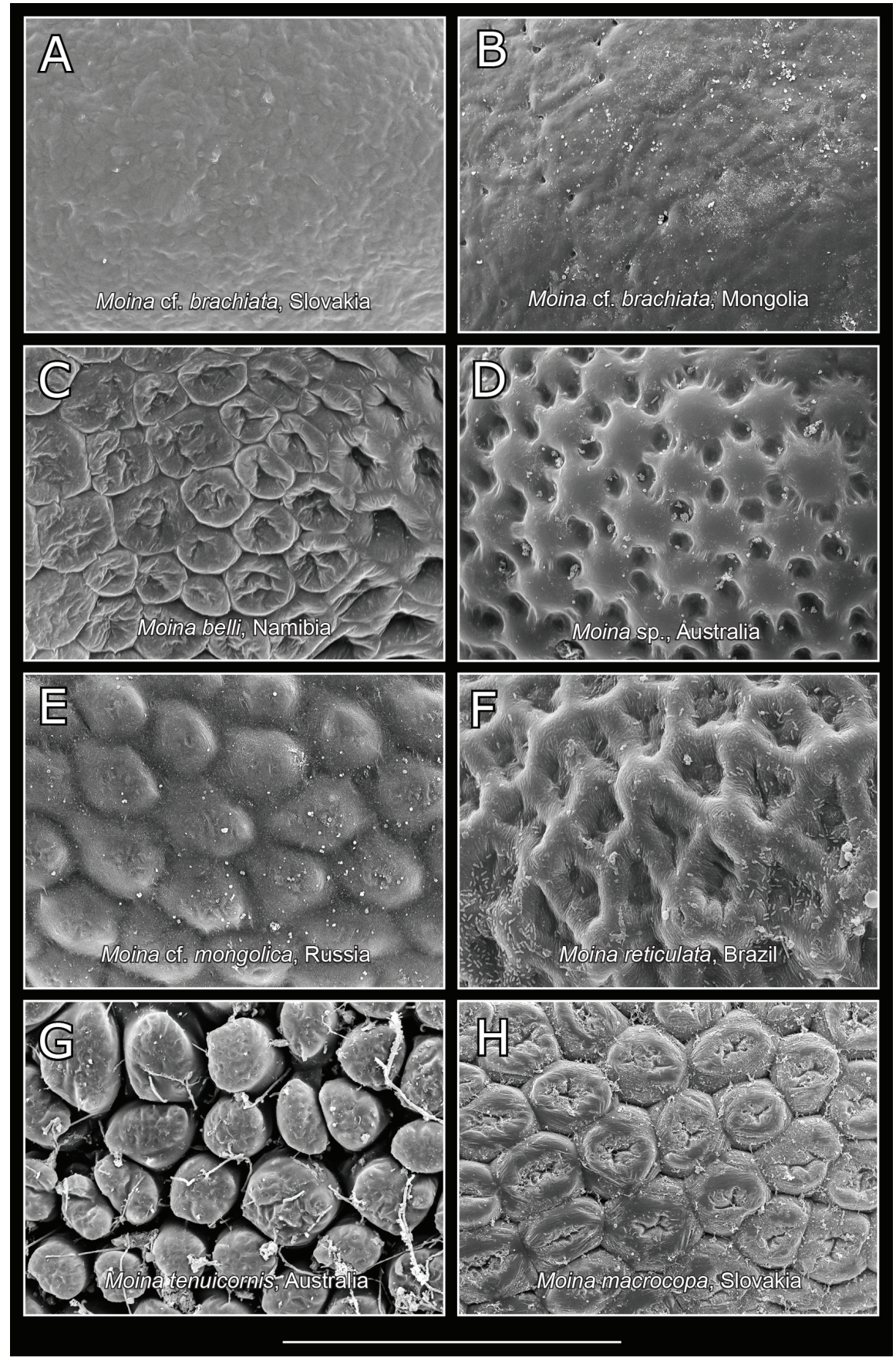

Figure 7. Variation of ephippial ultrastructure among different Moina species. All images are of the same magnification. A) Bač, Slovakia (27.07.1954). B) Yihe Modoto, Mongolia (06.09.1988). C) Avis Dam, Namibia (27.04.1972). D) North Victoria highway, Australia (05.02.1982). E) Schantrapay, Russia (26.07.1974). F) Lago Jacateringa, Brazil (02.09.1980). G) Alexandria, Australia (26.09.1973). H) Komárno, Slovakia (27.07.1954). Scale bar indicates $0.1 \mathrm{~mm}$ for all photographs. Variación de la ultraestructura efipial entre diferentes especies de Moina. Todas las imágenes son con la misma magnificación. A) Bač, Eslovaquia (27.07.1954). B) Yihe Modoto, Mongolia (06.09.1988). C) Presa de Avis, Namibia (27.04.1972). D) Carretera al norte de Victoria, Australia (05.02.1982). E) Schantrapay, Rusia (26.07.1974). F) Lago Jacateringa, Brasil (02.09.1980). G) Alexandria, Australia (26.09.1973). H) Komárno, Eslovaquia (27.07.1954). La barra de escala indica $0.1 \mathrm{~mm}$ para todas las fotografias. 
same species, and thus provide a solid base for future comparisons.

The geographical distribution of M. micrura s. str. remains unclear, but the available data (based on both genetic analyses and morphological comparisons) suggest that this species is restricted to Europe and the western part of the Palearctic. Apart from Central Europe, genetic data confirmed the presence of the same lineage also in the Middle East (Israel) and the Ponto Caspian region (Kazakhstan). Molecular analyses nevertheless showed that within Eurasia, numerous other lineages, presumably species, of the M. micrura complex reside (Bekker et al., 2016; this study), this is also true for Europe alone where genetically distinct lineages were detected in Hungary or Spain. Sequenced American (Elías-Gutiérrez et al., 2008; Prosser et al., 2013) and Australian populations (Petrusek et al., 2004) compared with all Eurasian sequences indicate that they are all distinct species as well, with K2P divergences at COI or $12 \mathrm{~S}$ exceeding $13 \%$ and $8 \%$, respectively. The distinctness of divergent clades of the complex are also supported by a hybridization experiment that demonstrated an apparent reproductive isolation between a European and an Australian clone (Petrusek et al., 2004).

A detailed redescription of morphology of $M$. micrura s. str. presented here provides a necessary step for disentangling of this rich species complex. Furthermore, we highlight a potential importance of ephippial ultrastructure for Moina systematics. This feature that was for long suspected as taxonomically relevant: Goulden (1966) suggested the possibility that the structure of the ephippial surface in Moina is crucial in the male's selection of the partner during mating, and is thus species-specific. As available identification keys cover presently-known members of the family Moinidae only partially, we have selected 15 gamogenetic populations of Moina micrura s. 1. from available samples collected on different continents, in which ephippia were present. To assess further the diversity of ephippial ultrastructures within the genus Moina, we added SEM pictures of nine additional species distinct from micrura-like populations (Figs. 6 and 7). Comparison of the ephippial surfaces revealed several distinct patterns of ornamentation. None of them resembles that of Moina micrura Kurz, 1875 and the feature seems to be a good differential character in species identification. Such substantial variation in the ephippial ultrastructure seems to support the Goulden's original hypothesis, although the potential role of this morphological character feature in establishing or maintenance of reproductive barriers between Moina species needs testing. In any case, these apparently species-specific characteristics of Moina ephippia open a possibility to develop keys for their routine identification in various limnological projects.

Most of above-mentioned morphological traits have not been described before, at least for the micrura complex. Future analysis of them is recommendable, to understand the evolution, adaptation and success of these organisms in different regions of the world. Any detailed study of these complexes also requires a detailed knowledge of the males and ephippial female morphology, because these often present more relevant species-specific traits to recognize the species than parthenogenetic females (as also shown for, e.g., Daphnia; Juračka et al., 2010; Popova et al., 2016). Although gamogenetic populations may occur only sporadically in the field, there is a possibility to induce sexual individuals in a laboratory culture, including hormonal stimulation to obtain males (Kim et al., 2006).

Combining detailed studies of morphology, with distribution data and molecular markers have been very useful to detangle complex groups of sibling species (Popova et al., 2016). The M. micrura complex would deserve a similar treatment in the future, redescription of M. micru$r a$ s. str. thus should be the beginning only.

Sequences from the COI gene will likely play a useful role in future identifications, as molecular techniques are becoming widespread even in routine biodiversity surveys and limnological projects. Unfortunately, in most cases when possible hidden taxa of cladocerans are uncovered by molecular tools, no nomenclatural act is realized, often due to the lack of reference material to compare (e.g., Elías-Gutiérrez et al., 2008), or due to the focus of the study other than taxonomy (e.g., Xu et al., 2016). However, to foster further research and appropriately recognize the diversity of groups in question in other biological 
fields (e.g., ecotoxicology), formally naming well-defined lineages, even cryptic species, should be considered (Fišer et al., 2018).

\section{CONCLUSIONS}

We can conclude that Moina micrura s. str. is distributed at least from Central Europe (with terra typica in the Czech Republic) to the Ponto Caspian region and Middle East but it seems to overlap in distribution with other related species (as a genetically distinct lineage has been detected in Hungary). Moina cf. micrura from Albufera Lake in Spain and Sobrón reservoir possibly is another, not yet described species that requires further attention. Is clear that European Moina micrura s. str. is distinct from analyzed populations from North and South America, Australia, Africa, Korea or Russia. The M. micrura-like populations from American continent are a complex of species, consisting of at least five distinct lineages that also require further, more detailed analyses. We hope this work, based on integrative taxonomy, establishes a baseline for future comparisons of M. micrura s. str. with other members of this complex, in order to facilitate its critical revision and the delimitation of species within.

\section{ACKNOWLEDGEMENTS}

The authors are thankful to Eduardo Vicente, Juan Miguel Soria and Javier Soria who assisted with the field collections and obtained part of the material presented here. Part of this work has been supported by Consejo de Ciencia y Tecnología (CONACyT) through a National grant and by Posgrado de Ciencias del Mar y Limnología to Lucía Montoliu-Elena. The Mexican Barcode of Life (Mexbol) node in Chetumal processed part of the material. Genomic Service and Scanning Electron Microscope Service (SCSIE, University of Valencia, Spain) and JEOL 6010 from ECOSUR Chetumal allowed comparisons of material. We also thank Daniel Vařecha and Markéta Vařechová (Odra Water Authority) who searched for Moina micrura in the region of northern Moravia and Silesia and to Ivo Přikryl (ENKI, Třeboň) who made available his data on the distribution of $M$. micrura and M. weismanni in the Czech Republic.
Curators of National Museum in Prague and Naturhistorisches Museum Wien, Petr Dolejš and Peter C. Dvorschak, kindly searched for possible Kurz's samples and types. Maria Rosa Miracle ${ }^{\dagger}$ was the first promotor of this work, and she also participated in discussions about this species and linked the Mexican and Czech groups to work in this difficult species.

\section{REFERENCES}

ALONSO, M. 1996. Crustacea, Branchiopoda. In: Fauna Ibérica, 7. Ramos, M. A., J. Alba, X. Bellés, J. Gonsálbes, A. Guerra, E. Macpherson, F. Martin, J. Serrano \& J. Templado (eds). Museo Nacional de Ciencias Naturales-CSIC, Madrid. Spain.

ASHFAQ, M., S. PROSSER, S. NASIR, M. MASOOD, S. RATNASINGHAM \& P. D. N. HEBERT. 2015. High diversity and rapid diversification in the head louse, Pediculus humanus (Pediculidae: Phthiraptera). Scientific Reports, 5: 14188. DOI: 10.1038/srep14188 BEKKER, E. I., D. P. KARABANOV, Y. R. GALIMOV \& A. A. KOTOV. 2016. DNA barcoding reveals high cryptic diversity in the North Eurasian Moina species (Crustacea: Cladocera). PLoS ONE, 11 (8): e0161737. DOI: 10.1371/journal.pone.0161737

BEKLEYEN, A. \& B. TAS. 2008. Zooplankton Fauna of Cernek Lake (Samsun). Ekoloji, 17 (82): 24-30.

CHATTERJEE, T., A. A. KOTOV, K. VAN DAMME, S. V. A. CHANDRASEKHAR \& S. PADHYE. 2013. An annotated checklist of the Cladocera (Crustacea: Branchiopoda) from India. Zootaxa, 3667: 1-89. DOI: 10.11646/zootaxa.3667.1.1

DAYRAT, B. 2005. Towards integrative taxonomy. Biological Journal of the Linnean Society, 85 (3): 407-415. DOI: 10.1111/j.1095-8312. 2005.00503.x

DEWAARD, J. R., V. SACHEROVA, M. E. A. CRISTESCU, E. A. REMIGIO, T. J. CREASE \& P. D. N. HEBERT. 2006. Probing the relationships of the branchiopod crustaceans. Molecular Phylogenetics and Evolution, 39 (2): 491-502. DOI: 10.1016/j.ympev. 2005.11 .003 
DUMONT, H. J., J. PENSAERT \& I. VAN DE VELDE. 1981. The crustacean zooplankton of Mali (West Africa). Hydrobiologia, 80 (2): 161-87.

EISCHEID, A. C., S. R. STADIG, S. M. HANDY, F. S. FRY \& J. DEEDS. 2016. Optimization and evaluation of a method for the generation of DNA barcodes for the identification of crustaceans. Journal of Food Science and Technology, 73: 357-67. DOI: 10.1016/j.lwt.2016.06.033

ELÍAS-GUTIÉRREZ, M., F. M. JERÓNIMO, N. V. IVANOVA, M. VALDEZ-MORENO M \& P. D. N. HEBERT. 2008. DNA barcodes for Cladocera and Copepoda from Mexico and Guatemala, highlights and new discoveries. Zootaxa, 1839: 1-42.

FIŠER, C., C. T. ROBINSON \& F. MALARD. 2018. Cryptic species as a window into the paradigm shift of the species concept. Molecular Ecology, 27(3): 613-635. DOI: 10.1111/mec.14486

FOLMER, O., M. BLACK, W. HOEH, R. LUTZ, R. VRIJENHOEK. 1994. DNA primers for amplification of mitochondrial cytochrome c oxidase subunit I from diverse metazoan invertebrates. Molecular Marine Biology and Biotechnology, 3 (5): 294-299.

GOULDEN, C. E. 1966. Co-occurrence of moinid Cladocera and possible isolating mechanisms. Verhandlungen des Internationalen Verein Limnologie, 16: 1669-1672.

GOULDEN, C. E. 1968. The Systematics and Evolution of the Moinidae. Transactions of the American Philosophical Society, 58 (6): $1-101$.

HAJIBABAEI, M., J. R. DE WAARD, N. V. IVANOVA, S. RATNASINGHAM, R. T. DOOH, S. L. KIRK, P. M. MACKIE \& P. D. N. HEBERT. 2005. Critical factors for assembling a high volume of DNA barcodes. Philosophical Transactions of the Royal Society of London Series B Biological Sciences, 360 (1462): 1959-1967. DOI: 10.1098/rstb.2005.1727

HEBERT, P. D. N., A. CYWINSKA, S. L. BALL \& J. R. DE WAARD. 2003a. Biological identifications through DNA barcodes. Proceedings of the Royal Society of London B: Biological Sciences, 270 (1512): 313-321. DOI: 10.1098/rspb.2002.2218

HEBERT, P. D. N., S. RATNASINGHAM \& J. R. DE WAARD. 2003b. Barcoding animal life: cytochrome c oxidase subunit 1 divergences among closely related species. Proceedings of the Royal Society of London B: Biological Sciences, 270 (Suppl. 1): S96-S99. DOI: 10.1098/rsbl.2003.0025

HUDEC, I. 1990. Moina weismanni Ishikawa, 1896 (Cladocera, Moinidae) in Central Europe. Hydrobiologia, 190: 33-42.

HUDEC, I. 2010. Fauna Slovenska III. Anomopoda, Ctenopoda, Haplopoda, Onychopoda (Crustacea: Branchiopoda). VEDA, Bratislava. Slovakia.

IDRIS, B. A. G. 1983. Freshwater zooplankton of Malaysia (Crustacea: Cladocera). Universiti Pertanian Malaysia Press, Pertanian. Malaysia. INTERNATIONAL COMMISSION ON ZOOLOGICAL NOMENCLATURE. 1999. International Code of Zoological Nomenclature, 4 th ed. International Trust for Zoological Nomenclature, London. UK.

JURAČKA， P. J., V. KOŘÍNEK. \& A. PETRUSEK. 2010. A new Central European species of the Daphnia curvirostris complex, Daphnia hrbaceki sp. nov. (Cladocera, Anomopoda, Daphniidae). Zootaxa, 2718: 1-22.

JURAČKA, P. J., V. SACHEROVÁ, I. DOBIÁS̆OVSKÁ I, D. BOVŠKOVÁ, Z. NOVOSADOVÁ, V. KOŘÍNEK \& A. PETRUSEK. 2016. Simplification of preparation techniques for scanning electron microscopy of Cladocera: preparing filtering limbs and ephippia for efficient studies of ultrastructure. Crustaceana, 89 (1): 47-62. DOI: 10.1163/15685403-00003513

KIM, K., A. A. KOTOV \& D. J. TAYLOR. 2006. Hormonal induction of undescribed males resolves cryptic species of cladocerans. Proceedings of the Royal Society of London B: Biological Sciences, 273 (1583): 141-147. DOI: $10.1098 / \mathrm{rspb} .2005 .3299$

KIMURA, M. 1980. A simple method for estimating evolutionary rates of base substitutions through comparative studies of nucleotide sequences. Journal of Molecular Evolution, 16 (1330): 111-120.

KOTOV, A. A., M. ELIAS-GUTIÉRREZ \& J. G. 
GRANADOS-RAMÍREZ. 2005. Moina dumonti sp. nov. (cladocera, anomopoda, moinidae) from southern Mexico and Cuba, with comments on Moinid limbs. Crustaceana 78(1): 41-57. DOI: $10.1163 / 1568540054024565$

KURZ, W. 1875. Dodekas neuer Cladoceren nebst einer kurzen Üebersicht der Cladocerenfauna Böhmens. Sitzungsberichte der Kaiserlichen Akademie der Wissenschaften. Mathematisch-Naturwissenschaftliche Classe, 70: 7-88 +3 pl.

LASSMANN, T. \& E. L. L. SONNHAMMER. 2005. Kalign - an accurate and fast multiple sequence alignment algorithm. BMC Bioinformatics, 6: 298. DOI: 10.1186/1471-21056-298

LI, Z., J. GUO, F. FANG, X. GAO, M. LONG, Z. LIU. 2012. Diversity and community structure of zooplankton in reservoirs in South China. In: Tropical and Sub-Tropical Reservoir Limnology in China. B.-P. Han \& Z. Liu (eds): 194-210. Springer, New York. USA. DOI: 10.1007/978-94-007-2007-7 1

MACHIDA, R. J., M. U. MIYA, M. NISHIDA \& S. NISHIDA. 2004. Large-scale gene rearrangements in the mitochondrial genomes of two calanoid copepods Eucalanus bungii and Neocalanus cristatus (Crustacea), with notes on new versatile primers for the srRNA and COI genes. Gene, 332 (1-2): 71-78. DOI: 10.1016/j.gene.2004.01.019

MONTERO-PAU, J., A. GÓMEZ \& J. MUÑOZ. 2008. Application of an inexpensive and high-throughput genomic DNA extraction method for the molecular ecology of zooplanktonic diapausing eggs. Limnology and Oceanography Methods, 6: 218-222. DOI: 10.4319/lom.2008.6.218

PARANAGUÁ, M. N., S. NEUMANN-LEITÃO, J. D. NOGUEIRA-PARANHOS, T. A. SILVA \& MATSUMURA-TUNDISI. 2005. Cladocerans (Branchiopoda) of a tropical estuary in Brazil. Brazilian Journal of Biolo$g y, 65$ (1): 107-115. DOI: 10.1590/S151969842005000100015

PARANHOS, J. D. N., V. L. D. S. ALMEIDA, J. P. SILVA FILHO, M. N. PARANAGUÁ, M. MELO-JÚNIOR \& NEUMANN-LEITÃO. 2013. The zooplankton biodiversity of some freshwater environments in Parnaíba basin (Piauí, Northeastern Brazil). Brazilian Journal of Biology, 73 (1): 125-134. DOI: 10.1590/S1519-69842013000100014

PETRUSEK, A. 2002. Moina (Crustacea: Anomopoda, Moinidae) in the Czech Republic (a review). Acta Societatis zoologicae Bohemicae, 66: 213-220.

PETRUSEK, A., M. ČERNÝ \& E. AUDENAERT. 2004. Large intercontinental differentiation of Moina micrura (Crustacea: Anomopoda): One less cosmopolitan cladoceran? Hydrobiologia, 526: 73-81. DOI: 10.1023/ B:HYDR.0000041612.08425.f0

POPOVA, E. V., A. PETRUSEK, V. KOŘÍNEK, J. MERGEAY, E. I. BEKKER, D. P. KARABANOV, Y. R. GALIMOV, T. V. NERETINA, D. J. TAYLOR \& A. A. KOTOV. 2016. Revision of the Old World Daphnia (Ctenodaphnia) similis group (Cladocera: Daphniidae). Zootaxa, 4161 (1): 1-40. DOI: 10.11646/zootaxa.4161.1.1

PROSSER, S., A. MARTÍNEZ-ARCE \& M. ELÍAS-GUTIÉRREZ. 2013. A new set of primers for COI amplification from freshwater microcrustaceans. Molecular Ecology Resources, 13 (6): 1151-1155. DOI: 10.1111/1755-0998.12132

PUILLANDRE, N., A. LAMBERT, S. BROUILLET \& G. ACHAZ. 2012. ABGD, Automatic Barcode Gap Discovery for primary species delimitation. Molecular Ecology, 21 (8): 1864-1877. DOI: $10.1111 /$ j.1365-294X. 2011.05239.x

RATNASINGHAM, S. \& P. D. N. HEBERT. 2007. BOLD: The Barcode of Life Data System (www.barcodinglife.org). Molecular Ecology Notes, 7: 355-364. DOI: 10.1111/j. 1471-8286.2006.01678.x

RATNASINGHAM, S. \& P. D. N. HEBERT. 2013. A DNA-based registry for all animal species: The Barcode Index Number (BIN) system. PLoS ONE, 8 (7): e66213. DOI: 10.1371/journal.pone.0066213

SAITOU, N. \& M. NEI. 1987. The neighbour-joining method: a new method for reconstructing phylogenetic trees. Molecular Biology and Evolution, 4 (4): 406-425.

SMIRNOV, N. N. 1976. Macrothricidae i Moini- 
dae fauny mira. Fauna SSSR. Rakoobraznye, 1(3). Nauka, Leningrad. SSSR.

SMIRNOV, N. N. \& B. V. TIMMS. 1983. A revision of the Australian Cladocera (Crustacea). Records of the Australian Museum, 1: $1-132$.

ŠRÁMEK-HUŠEK, R. 1940. K systematice a oekologii perloocky Moina micrura Kurz a ostatních Moin v Cechách. Časopis Národního muzea v Praze, 114: 204-214.

TAMURA, K., G. STECHER, D. PETERSON, A. FILIPSKI \& S. KUMAR. 2013. MEGA6: Molecular Evolutionary Genetics Analysis Version 6.0.
Molecular Biology and Evolution, 30 (12): 2725-2729. DOI: 10.1093/molbev/mst197

WAGLER, E. 1937. Crustacea. In: Die Tierwelt Mitteleuropas, 2(2a). P. Brohmer, P. Ehrmann \& G. Ulmer (eds): 3-224. Quelle \& Meyer, Leipzig. Germany.

XU, L., B. P. HAN, K.VAN DAMME, A. VIERSTRAETE, J. R. VANFLETEREN \& H. J. DUMONT. 2011. Biogeography and evolution of the Holarctic zooplankton genus Leptodora (Crustacea: Branchiopoda: Haplopoda). Journal of Biogeography, 38 (2): 359-70. DOI: 10.1111/j.1365-2699.2010.02409.x

Con el apoyo de:
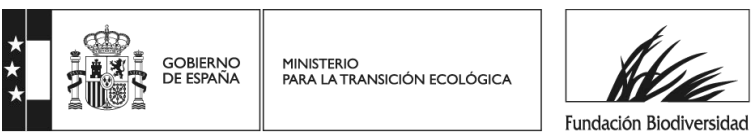